\title{
Neurotrophins regulate ApoER2 proteolysis through activation of the Trk signaling pathway
}

\author{
Jorge A Larios ${ }^{1,2,4}$, Ignacio Jausoro 1,2, Maria-Luisa Benitez ${ }^{1}$, Francisca C Bronfman ${ }^{2,3}$ and Maria-Paz Marzolo ${ }^{1,2^{*}}$
}

\begin{abstract}
Background: ApoER2 and the neurotrophin receptors Trk and $p 75^{\text {NTR }}$ are expressed in the CNS and regulate key functional aspects of neurons, including development, survival, and neuronal function. It is known that both ApoER2 and $\mathrm{p} 75^{\mathrm{NTR}}$ are processed by metalloproteinases, followed by regulated intramembrane proteolysis. TrkA activation by nerve growth factor (NGF) increases the proteolytic processing of p75 NTR mediated by ADAM17. Reelin induces the sheeding of ApoER2 ectodomain depending on metalloproteinase activity. However, it is not known if there is a common regulation mechanism for processing these receptors.

Results: We found that TrkA activation by NGF in PC12 cells induced ApoER2 processing, which was dependent on TrkA activation and metalloproteinases. NGF-induced ApoER2 proteolysis was independent of mitogen activated protein kinase activity and of phosphatidylinositol-3 kinase activity. In contrast, the basal proteolysis of ApoER2 increased when both kinases were pharmacologically inhibited. The ApoER2 ligand reelin regulated the proteolytic processing of its own receptor but not of $\mathrm{p} 75^{\mathrm{NTR}}$. Finally, in primary cortical neurons, which express both ApoER2 and TrkB, we found that the proteolysis of ApoER2 was also regulated by brain-derived growth factor (BDNF).

Conclusions: Our results highlight a novel relationship between neurotrophins and the reelin-ApoER2 system, suggesting that these two pathways might be linked to regulate brain development, neuronal survival, and some pathological conditions.
\end{abstract}

Keywords: ApoER2, Trk, p75 ${ }^{\text {NTR }}$, Neurotrophins, Reelin, Proteolytic processing, Shedding, PC12 cells

\section{Background}

The signaling of membrane surface receptors is regulated on a short-term basis by many different processes. Among these processes are posttranslational covalent modifications of the receptor's intracellular region, internalization of the receptor and its ligand followed by lysosomal degradation, and/or proteolytic processing induced by soluble or membrane-integrated proteases. This latter process has been studied in different membraneintegrated receptors that have a single-pass transmembrane region, such as the amyloid precursor protein (APP), Notch receptor, $\mathrm{p} 75^{\mathrm{NTR}}$ neurotrophin receptor $\left(\mathrm{p} 75^{\mathrm{NTR}}\right)$ and some members of the low density lipoprotein receptor family (LDLRs), including Apolipoprotein $\mathrm{E}$

\footnotetext{
* Correspondence: mmarzolo@bio.puc.cl

'Departamento de Biología Celular y Molecular, Laboratorio de Tráfico Intracelular y Señalización, Facultad de Ciencias Biológicas, Pontificia Universidad Católica, Alameda 340, Santiago 8320000, Chile ${ }^{2}$ Millenium Nucleus in Regenerative Biology (MINREB); Pontificia Universidad Católica de Chile, Alameda 340, Santiago 8320000, Chile

Full list of author information is available at the end of the article
}

receptor 2 (ApoER2), Megalin, and LRP1 [1-4]. The proteolytic processing of the receptors involves two general steps: 1) cleavage, called shedding, in the juxtamembrane extracellular domain, which results in the formation of a carboxy terminal membrane-integrated polypeptide (CTF, C-terminal fragment) and a soluble extracellular polypeptide (NTF, N-terminal soluble fragment), and 2) a second proteolysis event, carried out by the $\gamma$-secretase complex, at the transmembrane region of the membrane-integrated fragment, which produces two fragments, one of which corresponds to the intracellular domain (ICD) of the receptor [5]. In addition to regulating the half-life of the receptors, shedding and ICD production are processes that facilitate receptor signaling. For example, in the p $75^{\mathrm{NTR}}$ and Notch signaling pathways, the generation of proteolytic fragments is crucial for the correct signaling processes [6].

Many studies have focused on the mechanisms associated with the regulation of proteolytic processing of signaling receptors to understand the contribution of shedding 
to the intracellular signaling pathways. Neurotrophin receptors are among the principal study targets. The neurotrophins are trophic factors that act in the nervous system and regulate development and adult neuronal processes, such as neuronal survival or apoptosis [7], the outgrowth or withdrawal of neurites $[8,9]$, maturation and differentiation of sensory neurons [10], long-term depression (LTD) [11], and long-term potentiation (LTP) [12], among others [13]. Neurotrophin receptors include the Trk receptors (tyrosine kinase receptors). Binding of neurotrophins to a Trk receptor activates different signaling pathways, including the phosphatidylinositol 3-phosphate kinase (PI3K)/ AKT pathway, the mitogen-activated protein kinase pathway (MAPK/ERK), and the phospholipase $\mathrm{C}-\gamma$ pathway [13]. Nerve growth factor (NGF) binds to TrkA [14], brain-derived neurotrophic factor (BDNF) binds to TrkB [15], and neurotrophin 3 (NT3) binds to TrkC [16].

The neurotrophin receptor $\mathrm{p} 75^{\mathrm{NTR}}$, a member of the tumor necrosis factor (TNF) receptor superfamily, binds to all the neurotrophins with the same affinity, unlike the Trk receptors [17]. p $75^{\mathrm{NTR}}$, along with its ligands, induces the regulation of intracellular pathways, including the activation of the c-Jun N-terminal kinase (JNK) pathway [18], the regulation of the NF- $\mathrm{KB}$ transcription factor $[19,20]$, and the modulation of RhoA GTPase activity $[21,22]$. In the nervous system, $\mathrm{p} 75^{\mathrm{NTR}}$ has a role in neuronal apoptosis during nervous system development [23] and axon growth inhibition mediated by myelin and its interaction with the Nogo receptor, NgR1, and LINGO-1, which results in the activation of RhoA $[24,25]$. Furthermore, when $p 75^{\mathrm{NTR}}$ is co-expressed in neurons along with the Trk receptors, the apoptosis induced by $\mathrm{p} 75^{\mathrm{NTR}}$ signaling is abolished, and Trk receptor signaling is potentiated [26-29]. Many of the functions of $\mathrm{p} 75^{\mathrm{NTR}}$ in neurons are dependent on receptor proteolysis [30-39]. In PC12 cells, activation of TrkA by NGF induces the proteolytic processing of $\mathrm{p} 75^{\mathrm{NTR}}$, resulting in the accumulation of the $\mathrm{p} 75^{\mathrm{NTR}} \mathrm{CTF}$ and also its ICD [40]. Furthermore, shedding of p $75^{\text {NTR }}$ induced by NGF is mediated by the metalloprotease ADAM17 (a member of the disintegrin and metalloproteinase family), a process that facilitates NGF-TrkA signaling by stimulating the PI3K/AKT and MAPK/ERK pathways $[37,39]$. Similarly, in cerebellar granule neurons, the expression of $\mathrm{p} 75^{\mathrm{NTR}}$ facilitates AKT activation in response to the activation of TrkB by BDNF [37]. Another signaling process of $\mathrm{p} 75^{\mathrm{NTR}}$ that is mediated by proteolytic processing of the receptor is the apoptosis of sensory neurons. In these neurons, activation of the apoptotic pathway requires the production of the p $75^{\text {NTR }}$ ICD and the activation of the JNK pathway [38].

Another family of receptors expressed in the nervous system and related to brain development and adult neuronal functions is the LDLR family. Two receptors belonging to this family, ApoER2 and very low density lipoprotein receptor (VLDLR), together with their ligand reelin, are key components of the brain machinery involved in neuronal migration and positioning during brain development [41]. In this stage, reelin expressed by Cajal-Retzius cells [42,43] facilitates the correct development of different regions of the CNS, including the hippocampus, cerebellum, and cerebral cortex [44-47]. In the adult stage, the functions of ApoER2 and its ligand reelin include the regulation of synaptic plasticity [47,48], dendritic branching [49], actin remodeling [50], growth cone motility, filopodia formation [51], and neuronal survival [52,53].

Reelin is an extracellular matrix protein that binds to ApoER2 and VLDLR, triggering the activation of several intracellular signaling pathways [54] including the interaction between the Dab1 adaptor with the cytoplasmic region of the receptors [55,56]. Additionally, Dab1 is phosphorylated by the SRC family of kinases (SFK) [57-59], facilitating the activation of PI3K/AKT pathway [60]. PI3K regulates downstream effectors that are associated with cytoskeleton dynamics, such as cofilin $[50,61]$ and tau [62]. Like many surface receptors, ApoER2 signaling is regulated through lysosomal degradation after ligand binding and internalization [63]. Furthermore, as a result of the interaction between ApoER2 and its ligand, the receptor levels are downregulated by shedding [64], resulting in the production of the extracellular domain of the receptor and the carboxy-terminal fragment (ApoER2CTF), which is the substrate of the $\gamma$-secretase complex. Other ligands of ApoER2, such as Apolipoprotein E, alpha-2 macroglobulin $(\alpha 2 \mathrm{M})$ and F-spondin, also induce the proteolysis of the receptor $[64,65]$. However, there are few studies of the cellular mechanisms involved in the proteolysis of ApoER2 and the functional consequences that this process brings to the cells.

Both the reelin-ApoER2 and the neurotrophin signaling systems are expressed in neurons of the hippocampus, cerebellum, and cerebral cortex [13,44-47] and share functions associated with brain development and adult neuronal functions, including participation in some pathological conditions such as schizophrenia [66]. Moreover, the signaling machineries associated with both types of receptors share intracellular signaling molecules with the PI3K/AKT pathway. Interestingly, there is little direct evidence of crosstalk between these two signaling receptor families. However, ligand binding to LRP1, a member of LDLR family, transactivates the Trk receptors through an SFK-dependent pathway in PC12 cells and neurons [67], demonstrating that apolipoprotein E-receptors have neurotrophic activity that is dependent on Trk receptor transactivation.

The aim of this study was to determine whether the activation of the Trk receptors by neurotrophins regulates shedding of ApoER2. We demonstrated that NGF 
regulates the proteolysis of ApoER2 in PC12 cells and that this process is dependent on TrkA signaling. In this model, we also demonstrated the participation of two signaling pathways in the constitutive shedding of ApoER2: the MAPK/ERK and PI3K/AKT pathways. In contrast, reelin was not able to induce shedding of $\mathrm{p} 75^{\mathrm{NTR}}$. Finally, modulation of ApoER2 proteolysis was also identified in primary cultures of cortical neurons, in which BDNF also induced the shedding of ApoER2.

\section{Results \\ PC12 cells stably expressing ApoER2 respond to NGF and reelin}

PC12 cells have been widely used to study the neurotrophin signaling pathways and their cellular functions. PC12 cells endogenously express TrkA and $\mathrm{p} 75^{\mathrm{NTR}}$ and, in response to the exogenous NGF, differentiate into a "neuronal cell phenotype" similar to sympathetic neurons found in the PNS [68,69]. However, PC12 cells do not express high quantities of ApoER2. Therefore, to study the proteolysis of ApoER2, we generated stably transfected PC12 cells expressing the human full-length ApoER2 carrying an HA-tag at its N-terminus (HAApoER2) (Figure 1A). Western blot analysis using an antibody that recognizes the intracellular region of ApoER2 confirmed the expression of both the glycosylated (mature) and unglycosylated (immature) forms in cells transfected with the full-length receptor; additionally, some fragments of lower molecular weight, which represent proteolysis products, were also identified (Figure 1B). The receptor was localized throughout the cell, including the tips of the neurites in NGFdifferentiated cells, as determined via detection of the HA epitope by immunofluorescence (Figure 1C). ApoER2 transfected cells also responded to NGF by activation of AKT (Figure 1D).

PC12 cells that express HA-ApoER2 were activated by NGF in a similar way as the control cells (transfected with pcDNA3 plasmid) (Figure 2A). It is known that the ApoER2 ligand reelin induces neurite outgrowth in hippocampal and cortical neurons [70]. By PCR and by western blot, we confirmed the expression of the adaptor protein Dab1, which is required for the reelin canonical signaling pathway in PC12 cells (Figure 2B,C). In addition, we found that PC12 cells expressing ApoER2 respond to reelin; first, when they were treated with reelin-conditioned medium for $30 \mathrm{~min}$ it was possible to evidence the phosphorylation of Dab1 (Figure 2C) and second, the cells showed evident neurite extension after $48 \mathrm{~h}$ of incubation time with the ligand, (Figure 2D). Wild-type PC12 cells did not respond significantly to reelin (not shown), as expected from cells with low expression of endogenous ApoER2.

\section{NGF induces the proteolytic processing of ApoER2 in PC12 cells via TrkA}

Wild type PC12 cells have been previously used to study the mechanisms involved in the regulation of $\mathrm{p} 75^{\mathrm{NTR}}$ proteolytic processing induced by NGF [40]. Therefore, we investigated whether this process operates in a similar way in the PC12 cells stably expressing HA-ApoER2. Cells were incubated with different pharmacological inhibitors, and the effects of the drugs on the proteolysis of p75NTF were analyzed. Inhibiting the $\gamma$-secretase complex DAPT, which has been used to study the proteolysis of APP, Notch, and ApoER2, among others substrates, induced the accumulation of the CTF of p $75^{\mathrm{NTR}}$, thus corroborating the participation of the $\gamma$-secretase complex in the proteolysis of p $75^{\mathrm{NTR}}$ (Figure 3A). Furthermore, incubating the cells with NGF for 2 hours induced an increase in the CTF levels, as shown previously, indicating that NGF regulates the proteolysis of $\mathrm{p} 75^{\mathrm{NTR}}$ in our cell system. The proteolysis of $\mathrm{p} 75^{\mathrm{NTR}}$ was prevented by pre-incubating the cells for $1 \mathrm{~h}$ with K252a, an inhibitor of Trk tyrosine kinase activity, thus supporting the role of TrkA in this process [40]. It is known that the shedding of $\mathrm{p} 75^{\mathrm{NTR}}$ induced by NGF is mediated by ADAM17 [39]. Accordingly, when cells were pre-treated with GM6001, a broad spectrum inhibitor of the proteases belonging to the metalloproteinases family, the effect of NGF on $\mathrm{p} 75^{\mathrm{NTR}}$ proteolysis was almost completely suppressed. These results show that PC12 cells stably expressing HA-ApoER2 respond to TrkA-NGF signaling and regulate $\mathrm{p} 75^{\mathrm{NTR}}$ proteolysis, just as the wild type PC12 cells [40].

PC12-ApoER2 cells that were incubated with DAPT accumulated the ApoER2 $17 \mathrm{kDa}$ CTF, as has been previously described in other cell types, which supports the constitutive proteolytic processing of ApoER2 [4,64,71] (Figure 3B). PC12-ApoER2 cells that were incubated with NGF for $2 \mathrm{~h}$ showed a significant increase in the CTF level (Figure 3B,C). Similarly, PC12-ApoER2 cells displayed a gradual increase in the CTF level when they were incubated for different times with the neurotrophin, which evident already from 10 minutes of treatment (Figure 3D). This observation indicates that the proteolytic processing of ApoER2 is regulated by NGF. As a positive control for NGF activity, we determined the proteolysis of $\mathrm{p} 75^{\mathrm{NTR}}$ and the phosphorylation of AKT.

The fact that NGF binds to the TrkA receptor as well as $\mathrm{p} 75^{\mathrm{NTR}}$ led us to investigate which of the receptors is involved in the regulated proteolysis of ApoER2 induced by NGF. Pre-treatment of PC12-ApoER2 cells with K252a abolished the AKT phosphorylation induced by NGF and also abrogated the increase in ApoER2-CTF levels induced by the neurotrophin (Figure 4A,B). This result demonstrates that the regulated proteolysis of 

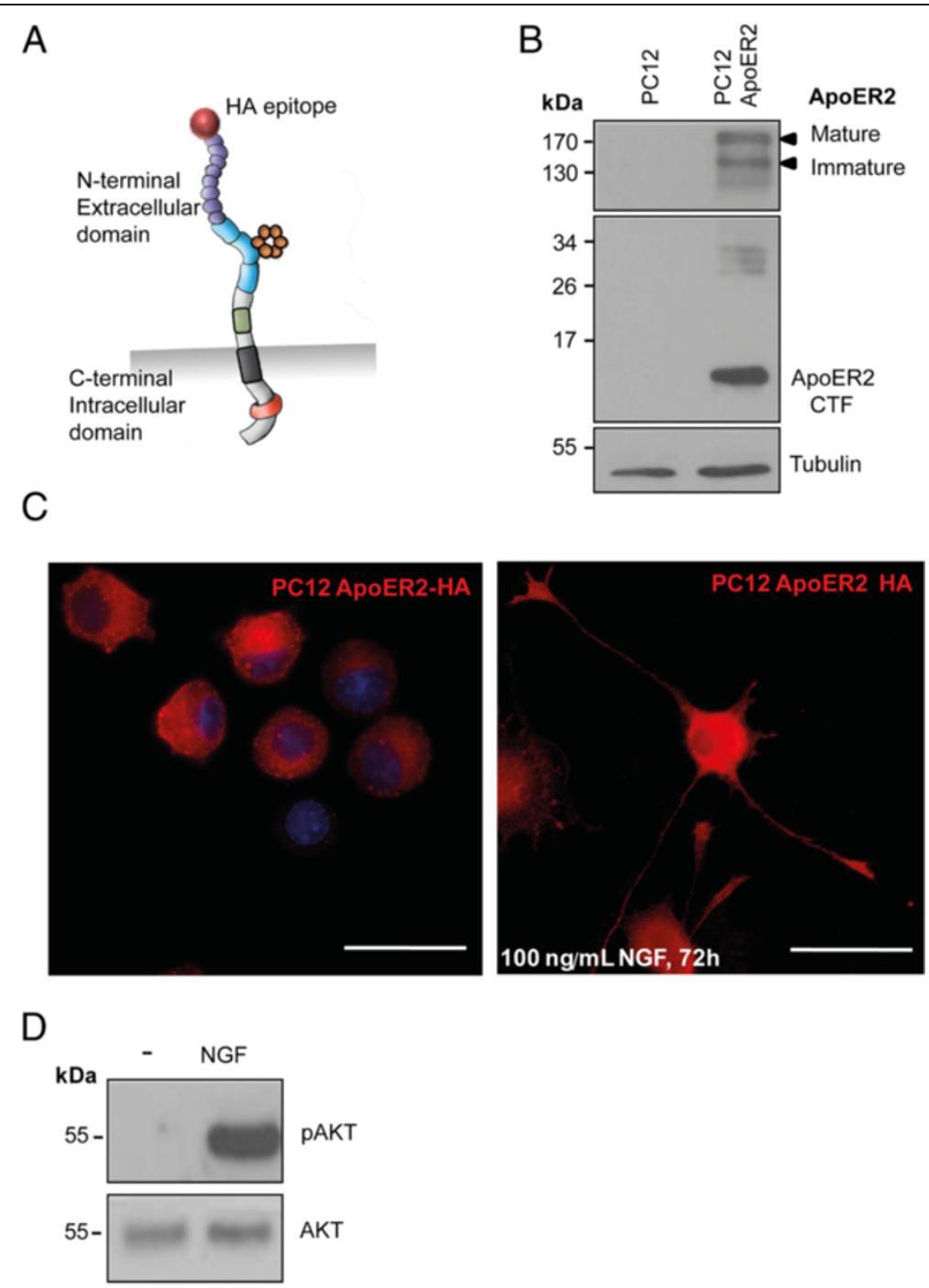

Figure 1 Characterization of PC12 cells stably expressing HA-ApoER2. (A) Schematic representation of the human HA-ApoER2 receptor transfected into PC12 cells. (B) Western blot showing the expression of HA-ApoER2 in stably transfected PC12 cells but not in wild type cells. ApoER2 was detected using an antibody that recognizes a region near the C-terminus of ApoER2. Both the mature (glycosylated) and immature forms ( 170 and $130 \mathrm{kDa}$ ) of the receptor were detected. There are also recognized fragments close to 26-34 kDa and $17 \mathrm{kDa}$ (corresponding to the receptor C-terminal fragment, CTF). a-tubulin is shown as a loading control. (C) Immunofluorescence of PC12 cells transfected with HA-ApoER2 (red) under basal conditions and after $72 \mathrm{~h}$ of NGF treatment $(100 \mathrm{ng} / \mathrm{mL})$ to induce differentiation. The cells expressed the receptor in different regions, including the plasma membrane and growth cones. Nuclear staining is shown in blue. Scale bar: $20 \mu \mathrm{m}$. (D) Western blots of cell lysates from PC12 cells stably expressing ApoER2. AKT phosphorylation was still detected after 2 h of incubation with NGF $(100 \mathrm{ng} / \mathrm{mL})$.

ApoER2 depends on TrkA activity and not on $775^{\text {NTR }}$ signaling.

Metalloproteinases of the ADAM family regulate the shedding of ApoER2 induced by NGF

Regulated proteolysis of many receptors, including p75 ${ }^{\text {NTR }}$ and ApoER2, is achieved by metalloproteinases $[64,72,73]$. When PC12 cells were incubated with a general inhibitor of metalloproteinases of the ADAM family (GM6001) $1 \mathrm{~h}$ prior to the addition of NGF, receptor proteolysis was significantly decreased (Figure 4C,D).
Therefore, this family of proteases is not only involved in $\mathrm{p} 75^{\mathrm{NTR}}$ shedding (Figure $3 \mathrm{~A}$ ) but also regulates the NGF-induced proteolytic processing of ApoER2.

\section{MAPK/ERK signaling pathway mediates $\mathrm{p} 75^{\mathrm{NTR}}$ but not ApoER2 proteolysis induced by NGF}

Among the signaling pathways activated by NGF is the MAPK/ERK signaling pathway, which has been shown to regulate the proteolysis of $\mathrm{p} 75^{\mathrm{NTR}}$ [39]. Therefore, to further analyze the mechanisms involved in the NGF-induced proteolysis of ApoER2, PC12 cells were incubated with 

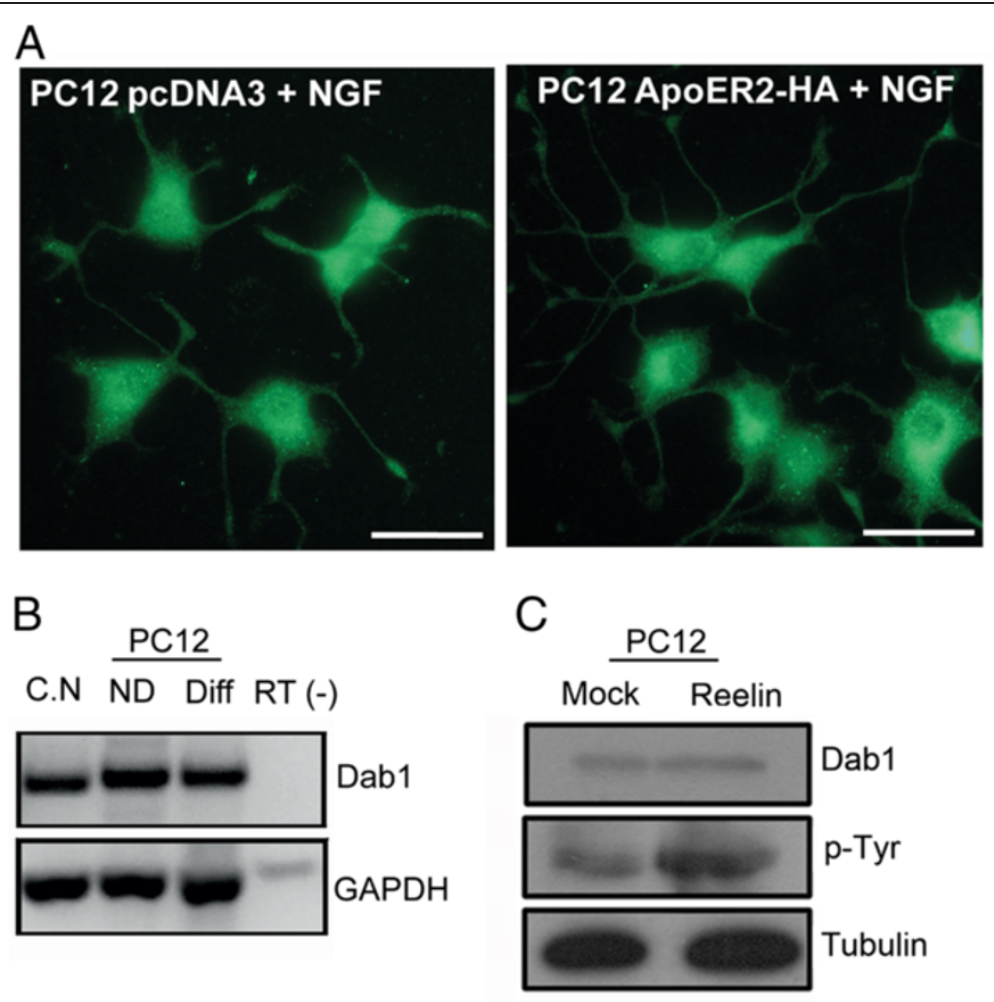

D

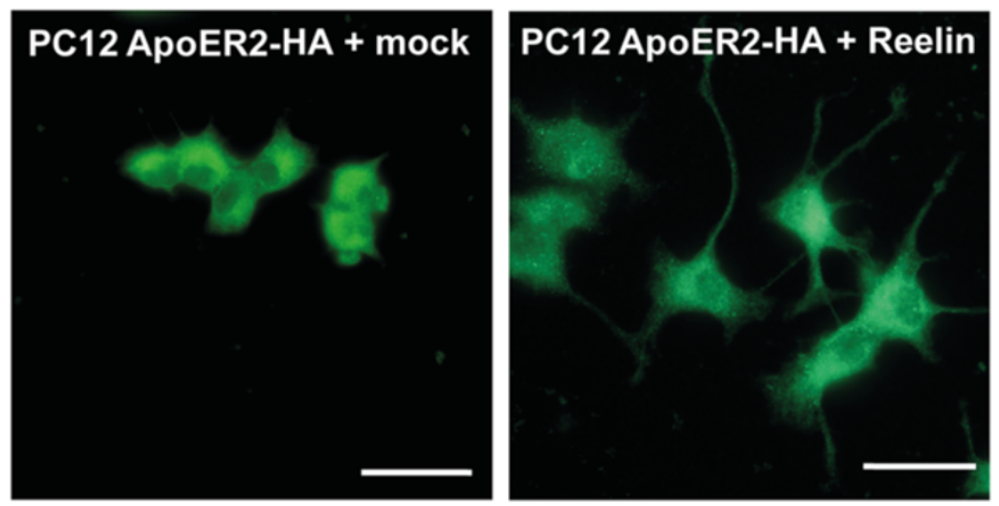

Figure 2 ApoER2 expression does not affect PC12 differentiation or responses to neurotrophin. (A) Differentiation of the PC12 control (pcDNA3) compared to cells stably expressing HA-ApoER2 with NGF (100 ng/mL) for $48 \mathrm{~h}$. In both conditions, the cells were able to differentiate and extend neurites. (B) PCR showing the expression of Dab1 in total brain, embryonic cortical neurons, and both differentiated and undifferentiated PC12 cells stably expressing ApoER2. (C) PC12 expressing HA-ApoER2 cell were incubated with reelin-conditioned media or mock-conditioned media (control) for $30 \mathrm{~min}$. Cells were lysed and the presence of total and phosphorylated Dab1 was detected by inmunoblot; $\mathrm{a}$-tubulin is shown as a loading control. (D) The presence of ApoER2 in PC12 cells makes them responsive to reelin-conditioned media (48 h of treatment), as assessed by neurite extension.

PD98059, an inhibitor of the ERK1/2 signaling pathway that controls MEK1/2 activity. Surprisingly, cells under this treatment displayed an increase in ApoER2 CTF levels, demonstrating that, under basal (no NGF) conditions, this MAPK/ERK signaling pathway downregulates the shedding of ApoER2 (Figure 5A,B). However, PC12 cells that were incubated with NGF in addition to the MEK1/2 inhibitor still showed an increase in the levels of ApoER2
CTF in response to the neurotrophin (Figure 5A,B) that was significantly higher than the CTF levels observed under basal MEK1/2 inhibition conditions. These results indicate that the MAPK/ERK signaling pathway is not involved in the proteolysis of ApoER2 induced by NGF. In contrast, the proteolysis of $\mathrm{p} 75^{\mathrm{NTR}}$ was dependent on the MAPK/ERK signaling pathway (Figure 5A,C). Therefore, although NGF stimulates the shedding of $\mathrm{p} 75^{\mathrm{NTR}}$ and 


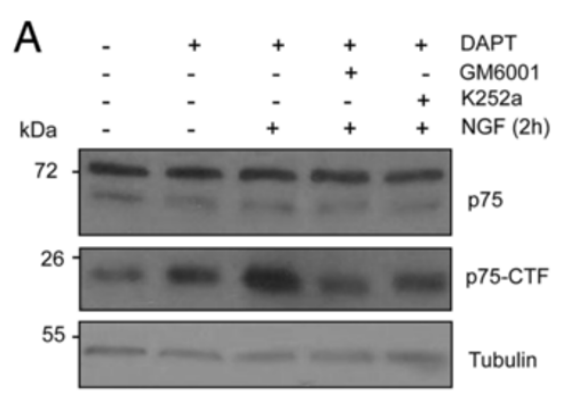

\section{B}

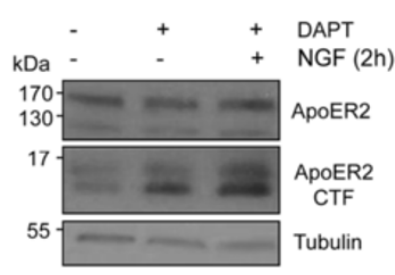

$\mathrm{D}$

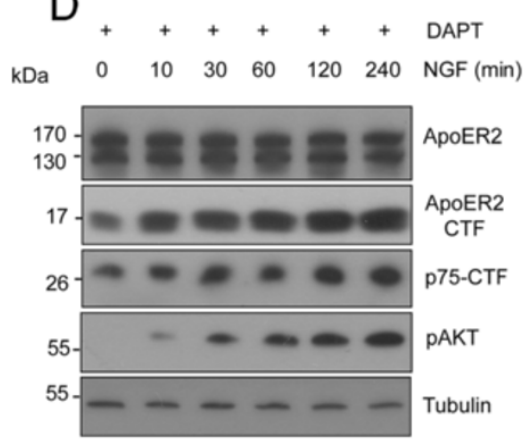

C

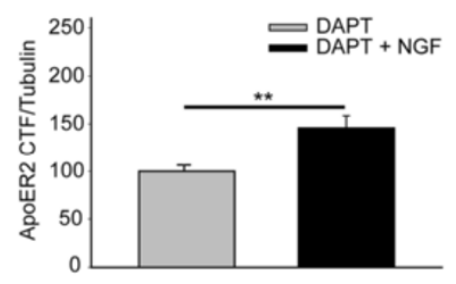

$\mathrm{E}$

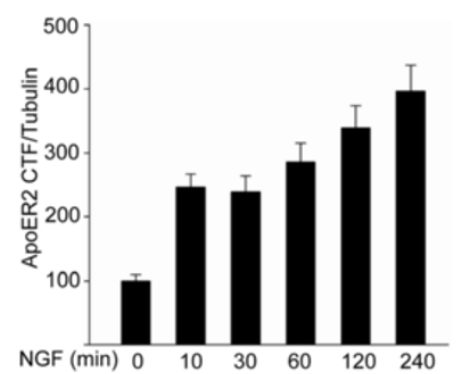

Figure 3 NGF induces the proteolytic processing of ApoER2. (A) Serum-starved PC12-ApoER2 cells were pre-treated with $10 \mu M$ DAPT ( $\gamma$-secretase complex inhibitor), 50 MM GM6001 (metalloproteases inhibitor) and/or $100 \mathrm{nM} \mathrm{K252a} \mathrm{(Trk} \mathrm{tyrosine} \mathrm{kinase} \mathrm{activity} \mathrm{inhibitor)} \mathrm{for} 1 \mathrm{~h}$ and then incubated with $100 \mathrm{ng} / \mathrm{mL}$ NGF for $2 \mathrm{~h}$. The blot shows full-length $\mathrm{p} 75^{\mathrm{NTR}}, \mathrm{p} 75^{\mathrm{NTR}} \mathrm{CTF}$, and a-tubulin as a loading control. As described [40], NGF induced the proteolysis of $\mathrm{p} 75^{\mathrm{NTR}}$ and, thus, the accumulation of the CTF. This process depends on TrkA tyrosine kinase activity and the metalloproteinases. (B) Cells were pre-treated with $10 \mu \mathrm{M}$ DAPT for $1 \mathrm{~h}$ and then incubated with $100 \mathrm{ng} / \mathrm{mL}$ NGF for $2 \mathrm{~h}$. ApoER2 and the proteolytic fragment ApoER2-CTF were recognized using antibodies against the intracellular region of the receptor. a-tubulin is shown as a loading control. (C) Quantification of blot levels of ApoER2-CTF normalized to the loading control a-tubulin and plotted as the average \pm SD of four independent experiments. Student's t-test, **P $<0.01$. (D) PC12-ApoER2 was treated as previously described and then incubated with $100 \mathrm{ng} / \mathrm{mL}$ NGF for different times (0-240 min). Cell lysates were used for protein detection by western blot analysis. AKT phosphorylation is observed immediately after the addition of NGF. as well as the apparition of p75NTR CTF. a-tubulin is shown as a loading control. (E) Quantification of blot levels of ApoER2-CTF normalized to the loading control a-tubulin and plotted as the average \pm SD of three independent experiments.

ApoER2, the signaling pathways involved in the proteolytic processing of the two receptors are different.

\section{PI3K activity reduces ApoER2 basal proteolysis but is not required for the NGF-induced processing}

Another signaling pathway that is activated in response to NGF is the PI3K signaling pathway. This pathway is also activated by ApoER2 in response to its ligand reelin. Furthermore, this signaling pathway is known to mediate, among several effects, neuronal survival through the regulation of the apoptotic machinery [74]. To address the role of PI3K in the NGF-induced processing of ApoER2, PC12 cells were incubated with different PI3K inhibitors. Two pan-class I/II/III PI3K inhibitors , LY 294002 (reversal) and Wortmannin (covalent; not shown) as well as the class I/II PI3K inhibitor (ZSTK474), that does not affects class III PI3K (Vps34, involved in membrane trafficking in the endosomal route) [75,76] were used and the ApoER2 and p75 ${ }^{\mathrm{NTR}}$ CTF levels were analysed by western blot (Figure 6A). Under basal conditions (no NGF) the CTF levels of both receptors were significantly increased following inhibitors treatment, indicating PI3K activity decreases the levels of the proteolytic fragments of the receptors (Figure 6B-E). Because all the inhibitors tested had the same effects, this suggests the possible involvement of class I/II and not class III PI3K. 

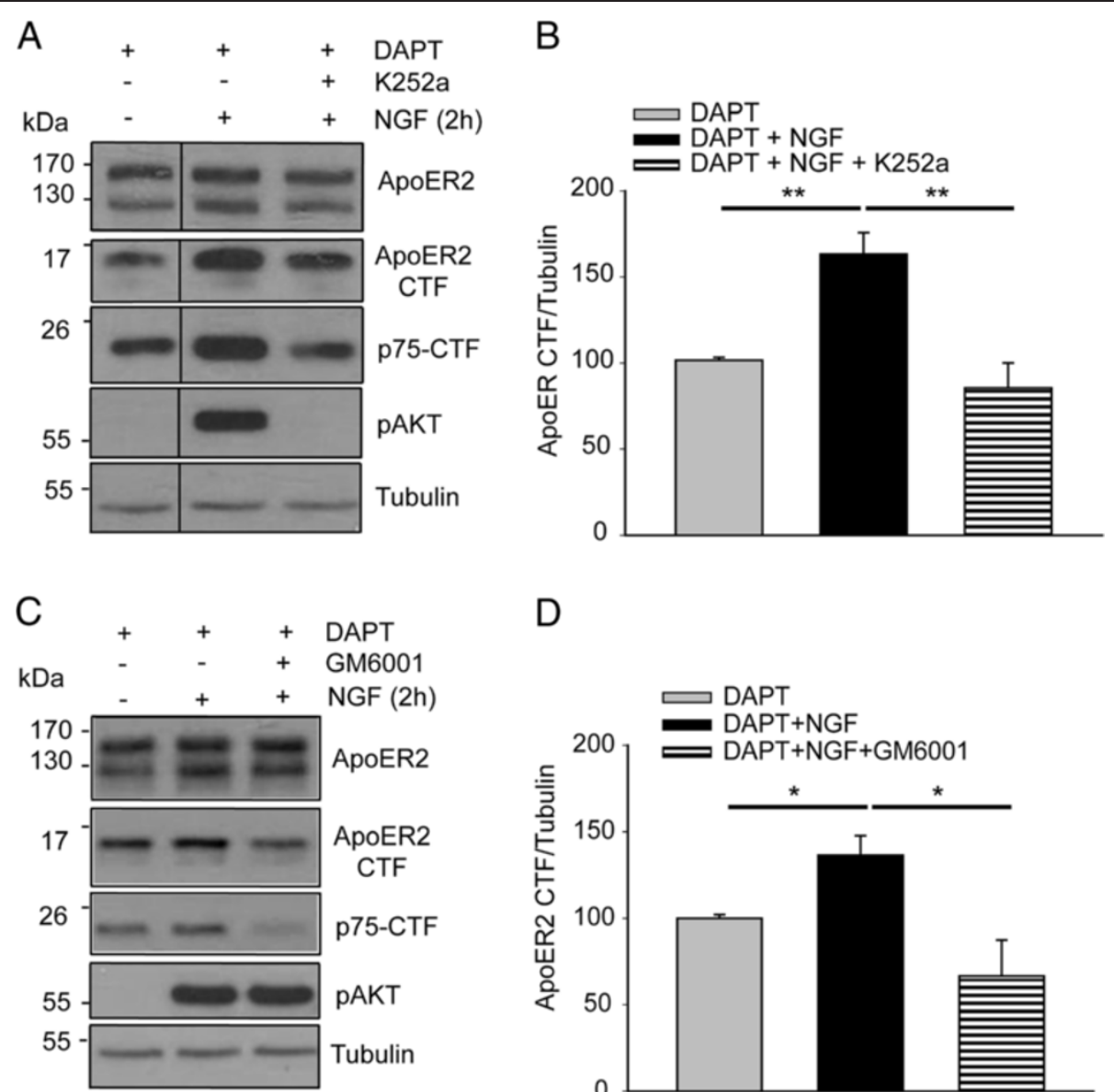

D

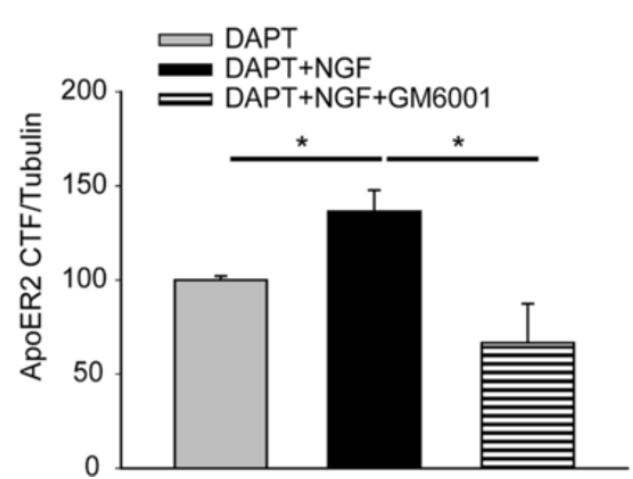

Figure 4 ApoER2 proteolysis induced by NGF depends on TrkA tyrosine kinase activity and on metalloproteinase activity. PC12-ApoER2

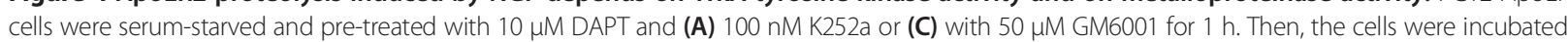
with $100 \mathrm{ng} / \mathrm{mL}$ NGF for $2 \mathrm{~h}$. ApoER2, ApoER2-CTF and the proteolytic fragment of p75 NTR (control) were determined by western blot analysis using antibodies directed against their intracellular regions. a-tubulin is shown as a loading control, and the phosphorylated form of AKT is a control for TrkA activation by NGF. (B and D) The levels of ApoER2 CTF were normalized to the loading control a-tubulin and plotted as the average \pm SD of three independent experiments. One way ANOVA, Holm-Sidak post-hoc test, **P $<0.01 ; * P<0.05$.

On the other hand, the NGF-induced processing of ApoER2 was not decreased when PI3K was inhibited; moreover the CTFs production was significantly increased under this condition, indicating that the machinery involved in the NGF-induced processing is not dependent on the activation of PI3K. In the same direction, the proteolysis of $\mathrm{p} 75^{\mathrm{NTR}}$ induced by NGF was not abolished, when PI3K activity was inhibited.

\section{ApoER2 proteolytic processing in cortical neurons}

To further study the connection between ApoER2 and the neurotrophin system, we searched for potential cross-talk between the pathways in cultured rat embryonic cortical neurons that are known to express both ApoER2 and the TrkB receptor. Upon activation with BDNF, a TrkB ligand, cortical neurons responded with an increase in AKT phosphorylation (Figure 7A). ApoER2 was detected in these neurons by immunofluorescence (Figure 7B) and by western blot analysis as a full-length protein as well as its 17-kDa CTF (Figure 7C). Furthermore, this low molecular weight fragment accumulated after treatment with DAPT (Figure 7B,C), which indicates that the $\gamma$-secretase complex, as expected, participates in the basal processing of ApoER2-CTF in cortical neurons. When DAPT-pretreated neurons were subsequently incubated with BDNF for $5 \mathrm{~h}$, the levels of the ApoER2 CTF significantly increased (Figure 7C,D), thus strengthening the data obtained in PC12 cells expressing HA-ApoER2 regarding the role of neurotrophins in receptor shedding.

\section{Reelin regulates ApoER2 degradation and proteolysis but not of p75}

Reelin downregulates the protein levels of ApoER2, inducing both proteolytic processing [64] and lysosomal degradation [63]. When PC12 HA-ApoER2 cells were treated with reelin, the levels of the mature form of the 


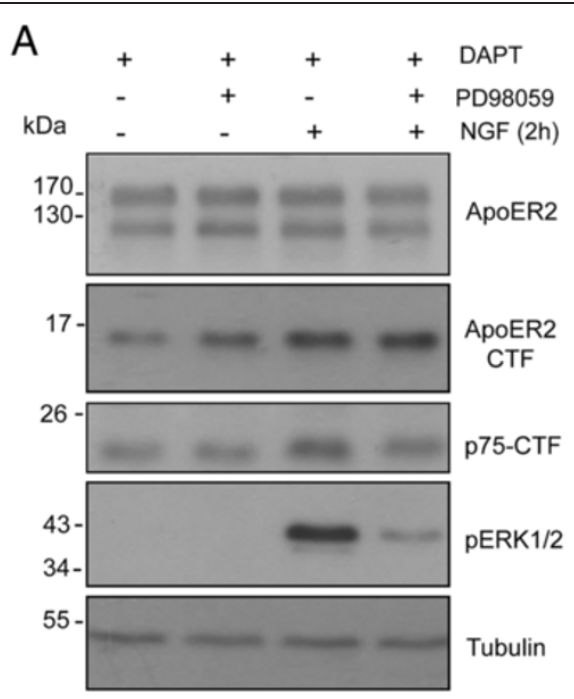

B

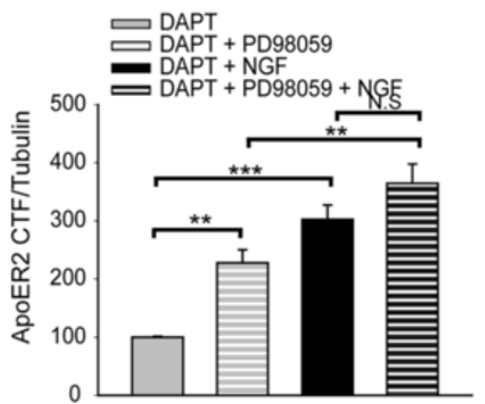

C

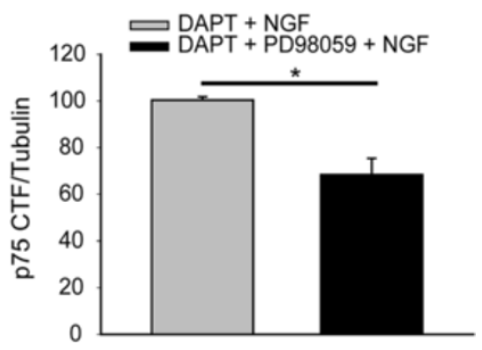

Figure 5 MEK1/2 activity regulates the constitutive proteolysis of ApoER2 but is not involved in ApoER2 shedding induced by NGF. (A) PC12-ApoER2 cells were serum-starved and pre-treated with $10 \mu \mathrm{M}$ DAPT and $25 \mu \mathrm{M}$ PD98059 for $1 \mathrm{~h}$. Then, the cells were incubated with $100 \mathrm{ng} / \mathrm{mL}$ NGF for $2 \mathrm{~h}$. ApoER2 and the proteolytic control p $75^{\text {NTR }}$ were recognized by western blotting using antibodies directed against their intracellular regions. The activation of MEK1/2 by NGF was evidenced by recognition of phospho-ERK. a-tubulin is shown as a loading control. The blot levels of ApoER2 CTF (B) and p75 NTR CTF (C) were normalized to the loading control a-tubulin and plotted as the average \pm SD of three independent experiments. One way ANOVA, Holm-Sidak post-hoc test, $* P<0.05, * * P<0.01, * * * P<0.001$, N.S, not significant.

receptor decreased (Figure 8A,B). Moreover, reelin induced the accumulation of the CTF of ApoER2, thus corroborating the role of this ligand in the proteolysis of ApoER2 (Figure 8A,C). To investigate crosstalk between the neurotrophin family and the reelin-ApoER2 system, we analyzed the levels of full-length $p 75^{\mathrm{NTR}}$ and the CTF of $775^{\text {NTR }}$ after treatment with reelin for $2 \mathrm{~h}$. The results indicated that, under this experimental condition, reelin does not affect the normal degradation of $\mathrm{p} 75^{\mathrm{NTR}}$ (Figure 8D,E,F ).

\section{Discussion}

The nervous system works as a complex network in which the neurons are the primary components. Many studies have shown the involvement of diverse signaling pathways both in the development of the nervous system and during adult stages. For example, the expression of neurotrophins and their receptors in neurons are crucial for the correct functioning of the CNS and PNS [9].
Similarly, reelin and its receptor ApoER2 participate in neuronal processes during development and in adulthood $[41,48,70,77,78]$. However, despite the large number of studies that have been conducted in neurons and the discovery of an enormous number of proteins involved in signaling, less is known about the connections between the different signaling systems functioning in the brain.

Based on reports showing that the neurotrophin and reelin signaling pathways share common intracellular effectors and that the receptors of both families are regulated by proteolytic processing, we studied whether crosstalk may exist between these two systems at the level of the regulation of proteolysis. As it was reported previously, $\mathrm{p} 75^{\mathrm{NTR}}$ proteolysis is regulated by the activation of TrkA receptor. Until now, there was no evidence of the regulation of other proteolytic processes involving Trk activation. In this work, we found that the activation of TrkA by NGF induced the proteolysis of ApoER2, 

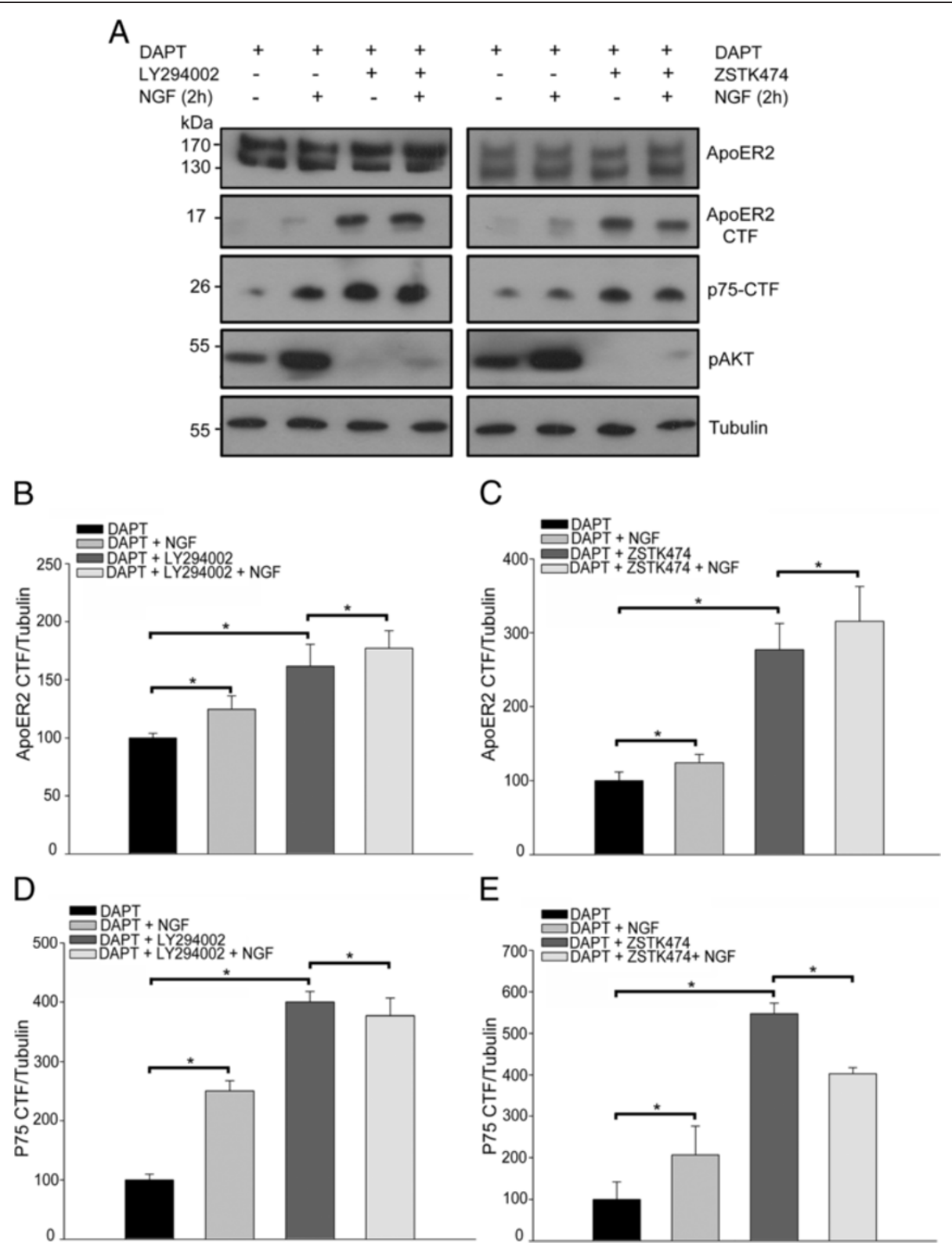

Figure 6 PI3K activity regulates the constitutive levels of ApoER2 CTF but is not involved in ApoER2 shedding induced by NGF. (A) PC12-ApoER2 cells were serum-starved and pre-treated with $10 \mu \mathrm{M}$ DAPT and $50 \mu \mathrm{M} \mathrm{LY} 294002$ or $5 \mu \mathrm{M}$ ZSTK474 for $1 \mathrm{~h}$. Then, the cells were incubated with $100 \mathrm{ng} / \mathrm{mL}$ NGF for $2 \mathrm{~h}$. ApoER2 and $\mathrm{p} 75^{\mathrm{NTR}}$ were recognized using antibodies directed against their intracellular regions. The activation of PI3K, induced by NGF, was determined by detection of phospho-AKT. a-tubulin is shown as a loading control. The blot levels of ApoER2 CTF (B and C) and of p $75^{\text {NTR }}$ CTF ( $\mathbf{D}$ and $\mathbf{E}$ ) were normalized to the loading control a-tubulin and plotted as the average \pm SD of three independent experiments. One way ANOVA, Holm-Sidak post-hoc test, $* P<0.01 ;$ N.S, not significant.

specifically affecting the shedding of the receptor and resulting in the accumulation of its CTF. These results demonstrate a connection between the neurotrophin system and the reelin pathway. Similar to the shedding of $\mathrm{p} 75^{\mathrm{NTR}}$ the TrkA-regulated proteolysis of ApoER2 was dependent on the metalloproteinases of the ADAM family. Although we did not identify the metalloproteinase involved in the shedding of ApoER2, the participation of the membrane integrated metalloproteinase ADAM17 has been described in the proteolysis of $\mathrm{p} 75^{\mathrm{NTR}}$ induced by NGF [39].

The shedding of p $75^{\mathrm{NTR}}$ induced by NGF in PC12 cells is dependent on MEK1/2 activity [39] and our data supported this finding. The activation of the MAPK/ERK pathway promotes the phosphorylation of ADAM17 [79]. The phosphorylation of ADAM17 in the intracellular region (threonine 735) is known to affect its intracellular localization, increase its concentration at the cell surface, 
A
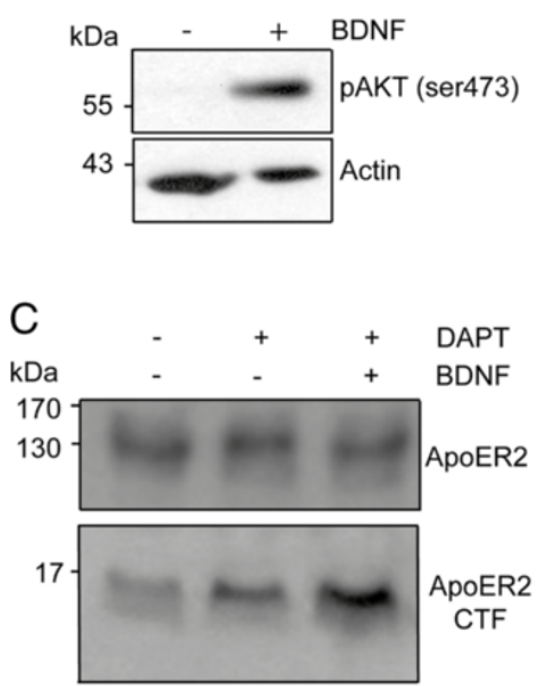

55

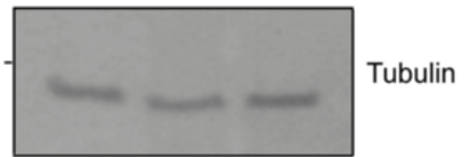

B

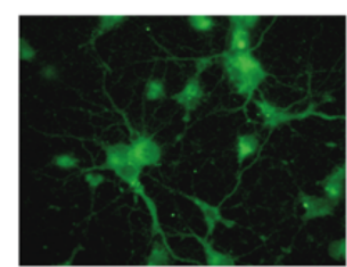

D

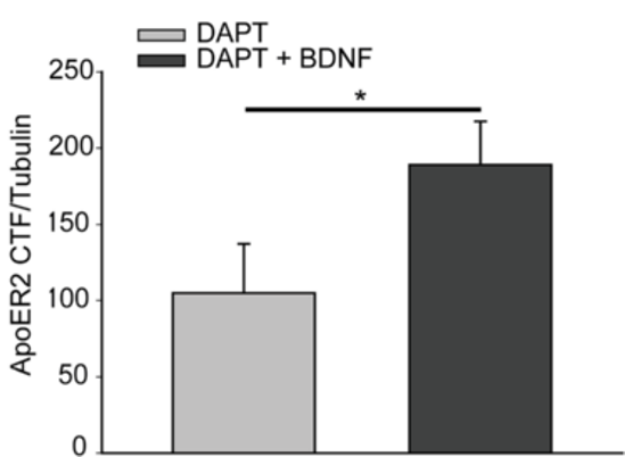

Figure 7 BDNF induces the proteolytic processing of ApoER2 in cortical neurons. (A) Cortical neurons (DIV 7) were treated with $100 \mathrm{ng} / \mathrm{mL}$ BDNF for 30 min. AKT phosphorylation levels shown are a result of TrkB activation by its ligand BDNF. Actin is shown as a loading control. (B) Immunofluorescence detection of ApoER2 in permeabilized cortical neurons from rat embryos using an antibody directed against the cytoplasmic domain of the receptor. (C) Serum-starved neurons were pre-treated with $10 \mu \mathrm{M}$ DAPT for $1 \mathrm{~h}$ and then incubated with $100 \mathrm{ng} / \mathrm{mL}$ BDNF for 5 h. ApoER2 was recognized from cell lysates using an antibody directed against its intracellular pro-rich region. a-tubulin is shown as a loading control. (D) The blot levels of ApoER2 CTF were normalized to the loading control a-tubulin and plotted as the average \pm SD of three independent experiments. Student's t-test, $* P<0.05$.

and facilitate its maturation [79]. Moreover, the proteolysis of $\mathrm{p} 75^{\mathrm{NTR}}$ induced by NGF is dependent on the phosphorylation of threonine 735 of ADAM17 [39]. However, while Kommaddi et al. showed that NGF stimulates ADAM17 phosphorylation, they did not observe a change in the surface levels of the metalloproteinase. Furthermore, activation of this signaling pathway is known not only to modulate the surface levels of the metalloproteinase but also to shift the balance from ADAM17 dimers to monomers. This process stimulates the dissociation of tissue inhibitor of metalloproteinase-3 (TIMP3) from ADAM17, thus activating the metalloproteinase [80]. Previous studies have shown that TIMP3 decreases the level of ApoER2-soluble extracellular fragments and CTFs, suggesting an active role for $\alpha$-secretase in the first step of ApoER2 processing at the plasma membrane [73]. In contrast, ApoER2 proteolysis induced by NGF was not dependent on MEK/ERK activation, which is the first difference between the regulated proteolysis of ApoER2 and $\mathrm{p} 75^{\mathrm{NTR}}$. This result suggests that the proteolysis of ApoER2 induced by NGF may be mediated by metalloproteinases other than ADAM17. Surprisingly, under basal conditions, our results show that MEK activity decreases the levels of the ApoER2 CTF, contrary to what is known about the regulation of ADAM17 activity on different substrates $[72,81]$. This result therefore strengthens the idea that other metalloproteinases participate in the shedding of ApoER2 under these conditions.

The PI3K/AKT pathway in neurons is another signaling pathway that is activated in response to NGF, and its activation is dependent on TrkA activity. The PI3kinases catalyze the phosphorylation of the phosphatidylinositols (PtdIns), a family of minority lipids present in the cytosolic side of cell membranes. Many of the products of PI3K (PtdIns3P, PtdIns(3,4)P2, PtdIns(3,5)P2, and PtdIns(3,4,5)P3) function in specific regions of the cell to recruit various proteins involved in protein trafficking and signaling $[82,83]$. Our results demonstrate that inhibiting the basal activity of PI3K via the pan-class I/II/III PI3K inhibitor LY 294002 as well as the class I/II PI3K inhibitor ZSTK474 [75,76] under a condition in which the activity of the $\gamma$-secretase complex is inhibited with DAPT, results in a significant accumulation of the proteolytic fragments of ApoER2. Many studies have shown the importance of PI3K in the trafficking of cell surface receptors through the endocytic pathway. For example, the transferrin receptor and receptors belonging to the LDLR family (LDLR, LRP1 and VLDLR) display impaired 


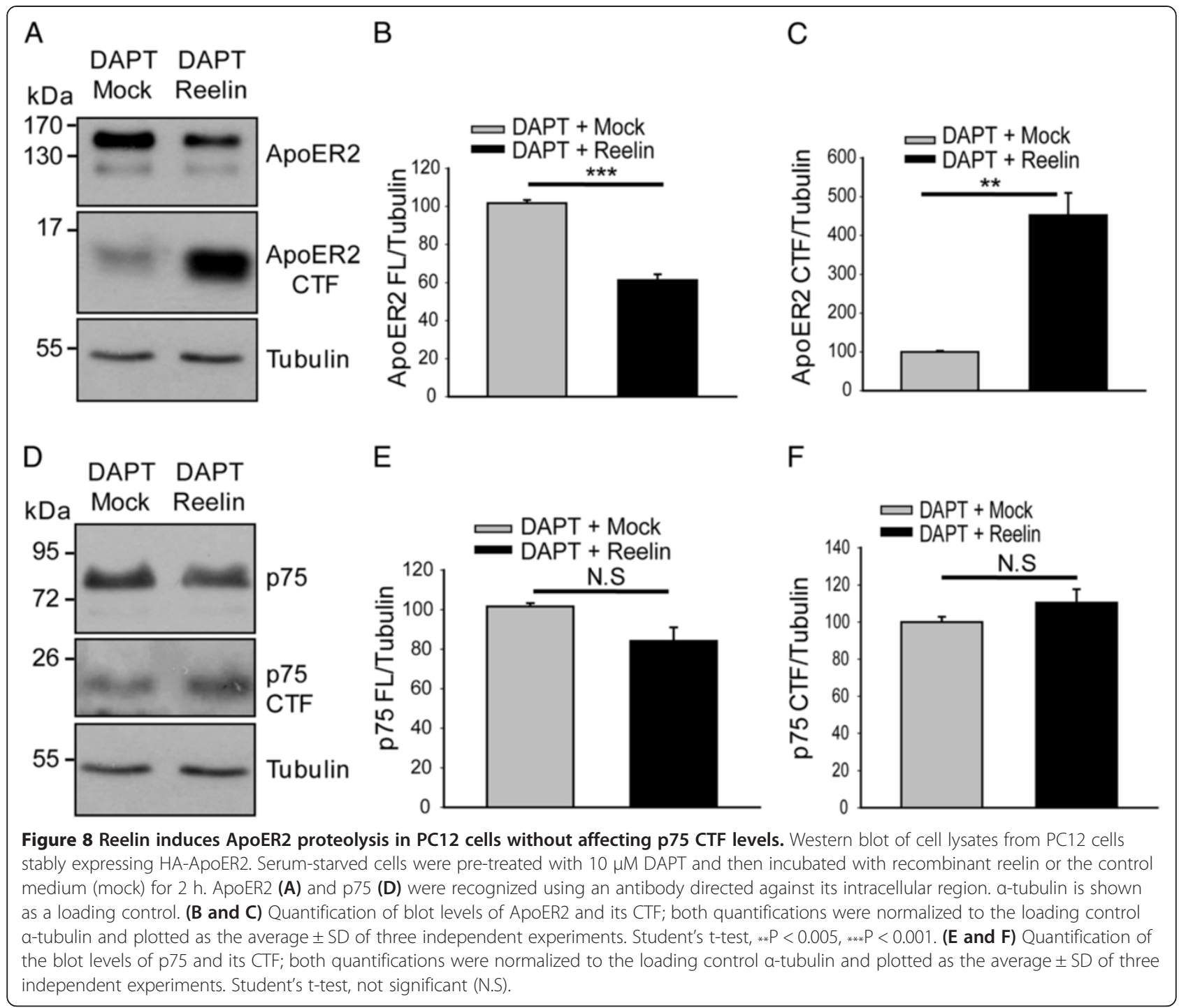

trafficking via the endocytic compartments after treatment with wortmannin $[84,85]$ a covalent pan-class I/II/III PI3K inhibitor. Specifically, the receptors accumulate in early endosomes and are prevented from progressing to late endosomes, which affects their lysosomal degradation, and also display impaired recycling to the cell surface. Therefore, the observed increase in the levels the CTF of ApoER2 (and also of p75 ${ }^{\mathrm{NTR}}$ ) when PI3K activity is inhibited could be due to an increase in receptor shedding and/ or reduced CTF degradation, by a $\gamma$-secretase independent pathway. Similarly to what we found for MEK/ERK activation, ApoER2 proteolysis induced by NGF was not dependent on PI3K activation. Thus, we suggest that the NGF-regulated proteolysis of ApoER2 does not depend on PI3K activity, in the same way of what was observed for p $75^{\text {NTR }}$.

Our results using cultures of primary cortical neurons demonstrate a connection between neurotrophin signaling and the proteolysis of endogenous ApoER2. The levels of ApoER2-CTF were regulated by BDNF, thus reinforcing the results obtained in PC12 cells. Our data, together with previous studies in neurons that show common functions and intracellular pathways between the neurotrophin and reelin-ApoER2 systems, suggest that these two families may be coordinated to regulate neuronal functions both during development and under different physiological conditions in the adult brain. A recent report indicated a genetic interaction between reelin and BDNF that is dependent on the sex hormones [86]. Moreover, the actions of BDNF in Cajal-Retzius cells during development decrease the expression of reelin [87], while the mRNA expression of VLDLR, the other reelin receptor, increases through TrkB [88]. Furthermore the Reeler mouse, which lacks reelin, has significantly decreased BDNF levels along with lower TrkB activity [89]. In addition, mice devoid of BDNF during development have significantly increased 
reelin levels [87]. Interestingly, the intracellular fragment of ApoER2 generated by the activity of the $\gamma$-secretase complex, the ApoER2-ICD, can inhibit the expression of reelin at the transcriptional level [90]. Therefore, the documented reduction of reelin induced by BDNF [87] could be dependent, at least in part, on the neurotrophin- induced proteolysis of ApoER2, as reported in our work. Overall, these data suggest a functional relationship between these two systems that may be relevant for pathological conditions such as schizophrenia [91-95] and autism [96-98].

ApoER2 is an endocytic receptor that follows the degradative pathway to the lysosomes in response to reelin binding [63]. Reelin also induces the proteolytic processing of the receptor by a still unknown mechanism $[4,64]$. When PC12 cells were treated with reelin and DAPT, the levels of mature ApoER2 decreased, and the CTF of the receptor accumulated. Therefore, in our cell model, receptor degradation is stimulated by its ligand. Reelin was also able to induce neurite outgrowth in PC12 cells expressing ApoER2, but it did not affect the levels of p $75^{\text {NTR }}$ or its CTF. These results indicate that, in contrast to the effect of NGF on ApoER2 processing, reelin signaling does not regulate the functionality of $\mathrm{p} 75^{\mathrm{NTR}}$ or the formation of its fragments. However, we could not discount that the processing of $\mathrm{p} 75^{\mathrm{NTR}}$ could be affected by reelin in a different cellular context because the levels of $\mathrm{p} 75^{\mathrm{NTR}}$ in our cortical neurons were too low to be detected as proteolytic fragments.

To date, little is known about the function of the proteolytic fragments of ApoER2. There are studies showing that the extracellular fragment of ApoER2 produced after shedding have the ability to interact with ligands found in the extracellular medium [99]. Additionally, the ApoER2-ICD can translocate to the nucleus [100] where, as mentioned before, it may be able to inhibit reelin transcription [90].

\section{Conclusions}

Even though the signaling pathway regulating ApoER2 shedding, induced by neurotrophins, was different than the one described for $\mathrm{p} 75^{\mathrm{NTR}}$ in terms of the participation of MEK1/2 activity, our study clearly gives new insights into the crosstalk between neurotrophins and the reelin receptors, specifically through the activation of ApoER2 shedding by the Trk receptors. In contrast, the ApoER2/reelin pathway would not regulate $\mathrm{p} 75^{\mathrm{NTR}}$ in terms in its proteolytic processing.

Further studies are required to understand the cellular role of the neurotrophin-induced ApoER2 processing in neurons. Plausible functions of ApoER2 processing, induced by its own ligand and/or by neurotrophin signaling, could be involved in fine-tuning the regulation of the reelin signaling cascade that should occur at the synapse and/or during neuronal migration.

\section{Methods}

\section{Antibodies}

We used a rabbit polyclonal antibody directed against a region near the C-terminal of ApoER2 (A3481, Sigma). The rabbit polyclonal antiserum against the recombinant human ApoER2 cytoplasmic domain and the mouse monoclonal anti-HA have been described before [101]. We also used a $\mathrm{p} 75^{\mathrm{NTR}}$ rabbit polyclonal antibody (07-476, Millipore), a mouse monoclonal anti- $\beta$-tubulin antibody (05-661, Millipore), a mouse monoclonal antiactin antibody (MAB1501R, Chemicon), a rabbit polyclonal anti-AKT antibody (\#9272, Cell Signaling), a rabbit monoclonal anti-phosphorylated AKT antibody (\#4060, Cell Signaling), a mouse monoclonal anti-phosphorylated ERK antibody (sc-7383, Santa Cruz Biotechnology), a rabbit polyclonal anti-Dab1 antibody (AB5840, Chemicon International), and a mouse monoclonal anti-MAP2 antibody (MAB378, Chemicon). We used horseradish peroxidase (HRP)-conjugated secondary antibodies (Chemicon) and Alexa 555- and 488-conjugated goat anti-mouse and anti-rabbit secondary antibodies (Molecular Probes).

\section{Plasmids}

The N-terminally HA-tagged full-length ApoER2 in the pCDNA3 vector [GenBank: NM_004631] was described previously $[101,102]$.

\section{Cell lines and culture conditions}

PC12 cells were maintained in DMEM-high glucose (Invitrogen) with 6\% fetal bovine serum [FBS, (Hyclone)], 6\% horse serum [HS, (Hyclone)], $100 \mathrm{U} / \mathrm{mL}$ penicillin and $100 \mu \mathrm{g} / \mathrm{mL}$ streptomycin in a $5 \% \mathrm{CO}_{2}$ incubator at $37^{\circ} \mathrm{C}$. PC12 cells were stably transfected with Lipofectamine 2000 reagent (Invitrogen) according to the manufacturer's protocol. The cells were selected with $0.8 \mathrm{mg} / \mathrm{mL}$ Geneticin [G418, (Hyclone)] and maintained with $0.4 \mathrm{mg} /$ mL G418. HEK-293 cell lines stably expressing reelin or the control vector pcDNA3 were grown in DMEM-high glucose supplemented with $10 \% \mathrm{FBS}, 100 \mathrm{U} / \mathrm{mL}$ penicillin, and $100 \mu \mathrm{g} / \mathrm{mL}$ streptomycin and maintained with $0.4 \mathrm{mg} / \mathrm{mL} \mathrm{G} 418$ in a $5 \% \mathrm{CO}_{2}$ incubator at $37^{\circ} \mathrm{C}$.

\section{Primary culture of rat embryonic cortical neurons}

The protocols to obtain neurons from rat (SpragueDawley) embryos were performed with approval from the Bioethical Board for animal studies at the Facultad de Ciencias Biológicas and according to the Guide for the Care and Use of Laboratory Animals of CONICYT. Cortical neurons were prepared and cultured essentially as described [71]. Cerebral cortexes from 18-day-old embryos were washed two times with cold Hank's medium 
and digested with Hank's 0.5\% trypsin-EDTA (Invitrogen) for $18 \mathrm{~min}$ at $37^{\circ} \mathrm{C}$. The tissue was resuspended in DMEM-high glucose supplemented with 10\% FBS, 100 $\mathrm{U} / \mathrm{mL}$ penicillin and $100 \mu \mathrm{g} / \mathrm{mL}$ streptomycin. Cells were counted and plated $\left(200,000\right.$ cells $\left./ \mathrm{cm}^{2}\right)$ in poly-Llysine (mol wt 30,000-70,000, Sigma) pre-treated Petri dishes and incubated in a $5 \% \mathrm{CO}_{2}$ incubator at $37^{\circ} \mathrm{C}$. After four hours, cell medium was replaced with a neuronal maintenance medium comprised of Neurobasal medium (Invitrogen), 1X B27 supplement (Invitrogen), $2 \mathrm{mM}$ L-Glutamine (Invitrogen), $100 \mathrm{U} / \mathrm{mL}$ penicillin and $100 \mu \mathrm{g} / \mathrm{mL}$ streptomycin. After $24 \mathrm{~h}$, the neurons were treated with $1 \mu \mathrm{M}$ arabinofuranosyl cytidine (Ara-C, from Sigma).

\section{Reelin conditioned medium}

HEK-293 cells stably expressing reelin or the control vector pcDNA3 were the kind gift of Dr. Tom Curran (University of Pennsylvania, USA). The cells were grown in $10-\mathrm{cm}$ plates until they reached $80 \%$ confluence in a $5 \% \mathrm{CO}_{2}$ incubator at $37^{\circ} \mathrm{C}$. They were washed once with PBS and incubated for $24 \mathrm{~h}$ with serum-free medium (DMEM-high glucose, $100 \mathrm{U} / \mathrm{mL}$ penicillin and $100 \mu \mathrm{g} /$ $\mathrm{mL}$ streptomycin) in a $5 \% \mathrm{CO}_{2}$ incubator at $37^{\circ} \mathrm{C}$. Later, the cell medium was collected and centrifuged at $1,000 \mathrm{rpm}$ for $5 \mathrm{~min}$, and the supernatant was stored at $4^{\circ} \mathrm{C}$. The remaining plates with cells were filled again with serum-free medium and incubated for $24 \mathrm{~h}$ in a $5 \%$ $\mathrm{CO}_{2}$ incubator at $37^{\circ} \mathrm{C}$. The collecting procedure was repeated a total of three times $(72 \mathrm{~h})$, and then the supernatant was concentrated 10 times using Amicon Ultra-15 centrifugal filter units with a $100 \mathrm{kDa}$ membrane cut-off, according to the manufacturer's protocol (Millipore).

\section{Cell treatments and Western blot analysis}

PC12 cells stably expressing HA-ApoER2 were grown in 6-well plates coated with poly-L-lysine. When the cells were $80 \%$ confluent, they were washed once with warm PBS and incubated with serum-free medium (DMEM high glucose) for $2 \mathrm{~h}$ in at $37^{\circ} \mathrm{C}$. After serum deprivation, the cell medium was replaced with fresh serum-free medium, and the corresponding inhibitory drugs were added for $1 \mathrm{~h}$ at $37^{\circ} \mathrm{C}$. For inhibitory agents, we used $100 \mathrm{nM} \mathrm{K252a}$ (Alomone Labs), $10 \mu \mathrm{M}$ DAPT, $25 \mu \mathrm{M}$ PD98058, $50 \mu \mathrm{M}$ GM6001 $100 \mathrm{nM}$ wortmannin and $50 \mu \mathrm{M}$ of LY294002 (all from Calbiochem) and $5 \mu \mathrm{M}$ of ZSTK474 (Selleck Chemicals LLC) Later, the cells were treated with $100 \mathrm{ng} / \mathrm{mL}$ NGF (Alomone Lab) for different times in a $5 \% \mathrm{CO}_{2}$ incubator at $37^{\circ} \mathrm{C}$. To treat the PC12 cells with reelin, the cells were incubated with either the ligand-enriched or the control medium (mock) for $2 \mathrm{~h}$ in a $5 \% \mathrm{CO}_{2}$ incubator at $37^{\circ} \mathrm{C}$. The cells were lysed with lysis buffer $(20 \mathrm{mM}$ Tris, $150 \mathrm{mM} \mathrm{NaCl}, 1 \%$ NP-40, 10\% glycerol, 2 mM EDTA, 1 mM PMSF, $4.7 \mu \mathrm{M}$ leupeptin, $1 \mu \mathrm{M}$ pepstatin, $1 \mu \mathrm{M}$ antipain, $1 \mu \mathrm{M}$ aprotinin, $1.5 \mu \mathrm{M}$ benzamidine, $1 \mathrm{mM}$ sodium orthovanadate, $5 \mathrm{mM} \mathrm{NaF}, 1 \mathrm{mM}$ glycerol phosphate) and centrifuged at $14,000 \mathrm{rpm}$ for $5 \mathrm{~min}$ at $4^{\circ} \mathrm{C}$, and the protein concentration of the supernatant was quantified with the BCA protein assay kit according to the manufacturer's protocol (Pierce). Samples were denatured in denaturing buffer (0.3 M Tris, 0.35 M SDS, 50\% glycerol, $0.05 \%$ blue bromophenol, and $25 \% \beta$-mercaptoethanol) by boiling for $5 \mathrm{~min}$. The proteins were subjected to SDS-PAGE under reducing conditions, transferred to a polyvinylidene difluoride (PVDF) membrane, and incubated with a blocking solution $(0.1 \%$ Tween-20, 5\% nonfat powdered milk, and PBS) for $30 \mathrm{~min}$ at room temperature. Later, the corresponding primary antibody was added (antitubulin 1:10,000; anti-ApoER2 A3481 1:10,000; antip75 ${ }^{\text {NTR }}$ 1:1,000; anti-p-ERK 1:1,000; anti-AKT 1:1,000; anti-p-AKT 1:1,000; anti-Dab1 1:1,000 and 1:1000 anti$\mathrm{p}$-Tyr) in blocking solution for $16 \mathrm{~h}$ at $4^{\circ} \mathrm{C}$. The PVDF membranes were washed with the blocking solution three times and incubated with HRP-conjugated antibodies $(1: 5,000)$ for $2 \mathrm{~h}$ at room temperature in blocking solution. Then, the immunoreactive proteins were detected using the ECL system according to the manufacturer's protocol (Pierce).

Rat cortical neurons were grown in 6-well plates for 7 DIV, washed once with warm serum-free medium (Neurobasal), and incubated with the same medium for $1 \mathrm{~h}$ in a $5 \% \mathrm{CO}_{2}$ incubator at $37^{\circ} \mathrm{C}$. After serum deprivation, the cell medium was replaced with fresh serum-free medium and the corresponding inhibitory drug, similar to the PC12 cell treatment described earlier. The neurons were incubated for $1 \mathrm{~h}$ in a $5 \% \mathrm{CO}_{2}$ incubator at $37^{\circ} \mathrm{C}$ and were later treated with $100 \mathrm{ng} / \mathrm{mL}$ BDNF (Alomone Labs, Jerusalem, Israel) for different times in a $5 \% \mathrm{CO}_{2}$ incubator at $37^{\circ} \mathrm{C}$. The cell lysis protocol and SDS-PAGE were performed as described for the PC12 cells.

\section{Determination of Dab1 mRNA expression}

Total RNA was extracted using the RNA-Solv ${ }^{\circ}$ Reagent (Omega Biotec). The extracted RNA was quantified by spectrophotometry at 260-nm optical density in a NanoDrop (ND-1000) Spectrophotometer (NanoDrop Technologies, Rockland, DE). For RT-PCR, first-strand synthesis was performed with the M-MLV reverse transcriptase (Thermo Scientific Inc.) In brief, $1 \mu \mathrm{g}$ of total RNA was incubated with DNase I for $15 \mathrm{~min}$ at room temperature. Then, $1 \mu \mathrm{L}$ of EDTA was added, and the reaction was incubated $10 \mathrm{~min}$ at $65^{\circ} \mathrm{C}$. Finally, $1 \mu \mathrm{L}$ of random primers were added, and the reaction was incubated at $70^{\circ} \mathrm{C}$ for $5 \mathrm{~min}$. After incubation, dNTPs, $10 \times$ PCR Buffer, RNase inhibitor, and reverse transcriptase were added, and the reaction was incubated at $25^{\circ} \mathrm{C}$ for $5 \mathrm{~min}$ followed by $25^{\circ} \mathrm{C}$ for $10 \mathrm{~min}, 42^{\circ} \mathrm{C}$ for $60 \mathrm{~min}$, and 
$70^{\circ} \mathrm{C}$ for $10 \mathrm{~min}$. The resulting cDNA was used for Dab1 PCR. The primers for Dab1 amplification were designed for optimal performance using the OligoAnalyzer 3.1 of the IDT Integrated DNA Technologies and Net primer free software from PREMIER Biosoft International (forward CATTGCGAAGGACATCACAG; reverse CGGC TTCACACTGCTTA). The cycling conditions for the amplified products were as follow: $95^{\circ} \mathrm{C}$ for 0.45 seconds, $50^{\circ} \mathrm{C}$ for $1 \mathrm{~min}, 72^{\circ} \mathrm{C}$ for 0.45 seconds ( 35 cycles). The amplified products were run on a $1 \%$ gel, and the bands were visualized under UV light after staining with Red Gel (Thermo Scientific Inc.).

\section{Immunofluorescence}

PC12 cells stably expressing HA-ApoER2 were plated on glass coverslips coated with poly-L-lysine. The cells were washed with PBS and fixed with 3\% paraformaldehyde solution (3\% PFA, 4\% sucrose and PBS) at room temperature for $15 \mathrm{~min}$. After three washes with PBS for 5 min each, the cells were permeabilized with $0.2 \%$ Triton X-100 in PBS for $10 \mathrm{~min}$ and then washed three times with PBS. Coverslips were incubated at room temperature with a blocking solution $(0.2 \%$ gelatin from bovine skin (Sigma) and PBS) for $1 \mathrm{~h}$. Later, the cells were incubated with a mouse anti-HA antibody diluted in blocking buffer at $4^{\circ} \mathrm{C}$ overnight. The coverslips were washed three times with PBS and then incubated with Alexa 555-conjugated anti-mouse antibody for $30 \mathrm{~min}$ at $37^{\circ} \mathrm{C}$. After three washes with PBS, the coverslips were mounted with Fluoromount mounting medium (Sigma) on glass slides.

The immunofluorescence protocol for cortical neurons was the same as that used for the PC12 cells, but a different blocking buffer [5\% gelatin from cold water fish skin (Sigma) and PBS] was used. Neurons were incubated with the anti-ApoER2 cytoplasmic domain antibody $(1: 1,000)$ in blocking buffer overnight at $4^{\circ} \mathrm{C}$. Coverslips were washed three times with PBS and then incubated with Alexa 555-conjugated anti-mouse antibody and Alexa 488-conjugated anti-rabbit antibody for $30 \mathrm{~min}$ at $37^{\circ} \mathrm{C}$. After three washes with PBS, the coverslips were mounted with Fluoromount mounting medium on glass slides.

\section{Statistical analysis}

Quantification of the blots was performed with the ImageJ $1.45 \mathrm{~s}$ software. Statistical analysis and graphing were performed with SigmaPlot 11.0 using Student's t-test or one way ANOVA with the Holm-Sidak post-hoc test, depending on the experiment.

\footnotetext{
Abbreviations

ADAM17: A Disintegrin and metalloproteinase 17; ApoER2: Apolipoprotein E receptor 2; APP: Amyloid precursor protein; BDNF: Brain-derived neurotrophic factor; CTF: C-terminal fragment; ICD: Intracellular domain; JNK: C-Jun N-
}

terminal kinase; LTD: Long term depression; LTP: Long-term potentiation; LDLR: Low density lipoprotein receptor; MAPK: Mitogen-activated protein kinase; MEK: Mitogen-activated protein kinase; NGF: Nerve growth factor; NTF: N-terminal fragment; NT3: Neurotrophin 3; PC12: Rat pheochromocytoma cell line; PI3K: Phosphatidylinositol 3 kinase; Ptdlns: Phosphatidylinositols; p75NTR: Neurotrophin receptor; SFK: Src family kinases; TIMP3: Tissue inhibitor of metalloproteinase-3; VLDLR: Very low density lipoprotein receptor.

\section{Competing interests}

The authors declare that they have no competing interests.

\section{Authors' contributions}

JAL designed and performed most of the experiments and drafted the manuscript and figures. IJ performed the experiments for new Figures 2, 3 and 6 in the revised manuscript. MLB performed the neuronal cultures and helped with the statistical analysis. MPM and FCB participated in the research and design of the study. MPM wrote the final manuscript and organized the figures. All authors read and approved the final manuscript.

\section{Acknowledgements}

We want to thank Dr. Tom Curran (University of Pennsylvania, USA) for providing us with the reelin-expressing HEK cell lines and Romina Falcon (Dr. Bronfman Lab) for producing the PC12 cells stably expressing ApoER2. This study was supported by the Fondo Nacional de Ciencia y Tecnología, FONDECYT through grant \#1110382 to MPM and grant \#1085273 to FB. This study was also supported by the Millennium Nucleus in Regenerative Biology (MINREB), RC120003, ICM Program to MPM and FB.

\section{Author details}

${ }^{1}$ Departamento de Biología Celular y Molecular, Laboratorio de Tráfico Intracelular y Señalización, Facultad de Ciencias Biológicas, Pontificia Universidad Católica, Alameda 340, Santiago 8320000, Chile. ${ }^{2}$ Millenium Nucleus in Regenerative Biology (MINREB); Pontificia Universidad Católica de Chile, Alameda 340, Santiago 8320000, Chile. ${ }^{3}$ Departamento de Fisiología, Laboratorio de Neurobiología Celular y Regeneración. Facultad de Ciencias Biológicas, Pontificia Universidad Católica, Alameda 340, Santiago 8320000, Chile. ${ }^{4}$ Department of Biochemistry, University of Geneva, Geneva, Switzerland.

Received: 26 April 2014 Accepted: 15 September 2014 Published: 19 September 2014

\section{References}

1. Marzolo MP, Bu G: Lipoprotein receptors and cholesterol in APP trafficking and proteolytic processing, implications for Alzheimer's disease. Semin Cell Dev Biol 2009, 20(2):191-200.

2. Fortini ME: Notch signaling: the core pathway and its posttranslational regulation. Dev Cell 2009, 16(5):633-647.

3. Skeldal S, Matusica D, Nykjaer A, Coulson EJ: Proteolytic processing of the $p 75$ neurotrophin receptor: a prerequisite for signalling?: neuronal life, growth and death signalling are crucially regulated by intra-membrane proteolysis and trafficking of p75(NTR). Bioessays 2011, 33(8):614-625.

4. Larios JA, Marzolo MP: Novel aspects of the apolipoprotein-E receptor family: regulation and functional role of their proteolytic processing. Front Biol 2012, 7(2):113-143.

5. Wakabayashi T, De Strooper B: Presenilins: members of the gamma-secretase quartets, but part-time soloists too. Physiology (Bethesda) 2008, 23:194-204.

6. Bronfman FC: Metalloproteases and gamma-secretase: new membrane partners regulating 755 neurotrophin receptor signaling? I Neurochem 2007, 103(Suppl 1):91-100.

7. Lu B, Pang PT, Woo NH: The yin and yang of neurotrophin action. Nat Rev Neurosci 2005, 6(8):603-614

8. Campenot RB: Local control of neurite development by nerve growth factor. Proc Natl Acad Sci U S A 1977, 74(10):4516-4519.

9. Davies AM: Neurotrophins: neurotrophic modulation of neurite growth. Curr Biol 2000, 10(5):R198-R200.

10. Wright EM, Vogel KS, Davies AM: Neurotrophic factors promote the maturation of developing sensory neurons before they become dependent on these factors for survival. Neuron 1992, 9(1):139-150. 
11. Rosch H, Schweigreiter R, Bonhoeffer T, Barde YA, Korte M: The neurotrophin receptor p75NTR modulates long-term depression and regulates the expression of AMPA receptor subunits in the hippocampus. Proc Natl Acad Sci U S A 2005, 102(20):7362-7367.

12. Patterson SL, Abel T, Deuel TA, Martin KC, Rose JC, Kandel ER: Recombinant BDNF rescues deficits in basal synaptic transmission and hippocampal LTP in BDNF knockout mice. Neuron 1996, 16(6):1137-1145.

13. Reichardt LF: Neurotrophin-regulated signalling pathways. Philos Trans $R$ Soc Lond B Biol Sci 2006, 361(1473):1545-1564.

14. Klein $R$, Jing SQ, Nanduri V, O'Rourke E, Barbacid M: The trk proto-oncogene encodes a receptor for nerve growth factor. Cell 1991, 65(1):189-197.

15. Klein R, Nanduri V, Jing SA, Lamballe F, Tapley P, Bryant S, Cordon-Cardo C, Jones KR, Reichardt LF, Barbacid M: The trkB tyrosine protein kinase is a receptor for brain-derived neurotrophic factor and neurotrophin-3. Cell 1991, 66(2):395-403.

16. Lamballe $F$, Klein $R$, Barbacid M: trkC, a new member of the trk family of tyrosine protein kinases, is a receptor for neurotrophin-3. Cell 1991, 66(5):967-979

17. Rodriguez-Tebar A, Dechant G, Barde YA: Neurotrophins: structural relatedness and receptor interactions. Philos Trans R Soc Lond B Biol SCi 1991, 331(1261):255-258.

18. Casaccia-Bonnefil P, Carter BD, Dobrowsky RT, Chao MV: Death of oligodendrocytes mediated by the interaction of nerve growth factor with its receptor p75. Nature 1996, 383(6602):716-719.

19. Hamanoue M, Middleton G, Wyatt S, Jaffray E, Hay RT, Davies AM: p75-mediated NF-kappaB activation enhances the survival response of developing sensory neurons to nerve growth factor. Mol Cell Neurosci 1999, 14(1):28-40.

20. Casaccia-Bonnefil P, Gu C, Khursigara G, Chao MV: p75 neurotrophin receptor as a modulator of survival and death decisions. Microsc Res Tech 1999, 45(4-5):217-224.

21. Yamashita T, Tucker KL, Barde YA: Neurotrophin binding to the p75 receptor modulates Rho activity and axonal outgrowth. Neuron 1999, 24(3):585-593

22. Yamashita T, Tohyama M: The p75 receptor acts as a displacement factor that releases Rho from Rho-GDI. Nat Neurosci 2003, 6(5):461-467.

23. Van der Zee CE, Ross GM, Riopelle RJ, Hagg T: Survival of cholinergic forebrain neurons in developing p75NGFR-deficient mice. Science 1996, 274(5293):1729-1732.

24. Wang KC, Kim JA, Sivasankaran R, Segal R, He Z: P75 interacts with the Nogo receptor as a co-receptor for Nogo, MAG and OMgp. Nature 2002, 420(6911):74-78.

25. Wong ST, Henley JR, Kanning KC, Huang KH, Bothwell M, Poo MM: A p75 (NTR) and Nogo receptor complex mediates repulsive signaling by myelin-associated glycoprotein. Nat Neurosci 2002, 5(12):1302-1308.

26. Berg MM, Sternberg DW, Hempstead BL, Chao MV: The low-affinity p75 nerve growth factor (NGF) receptor mediates NGF-induced tyrosine phosphorylation. Proc Natl Acad Sci U S A 1991, 88(16):7106-7110.

27. Hantzopoulos PA, Suri C, Glass DJ, Goldfarb MP, Yancopoulos GD: The low affinity NGF receptor, p75, can collaborate with each of the Trks to potentiate functional responses to the neurotrophins. Neuron 1994, 13(1):187-201.

28. Kahle P, Barker PA, Shooter EM, Hertel C: p75 nerve growth factor receptor modulates p140trkA kinase activity, but not ligand internalization, in PC12 cells. J Neurosci Res 1994, 38(5):599-606.

29. Verdi JM, Birren SJ, Ibanez CF, Persson H, Kaplan DR, Benedetti M, Chao MV, Anderson DJ: p75LNGFR regulates Trk signal transduction and NGF-induced neuronal differentiation in MAH cells. Neuron 1994, 12(4):733-745.

30. Majdan M, Lachance C, Gloster A, Aloyz R, Zeindler C, Bamji S, Bhakar A, Belliveau D, Fawcett J, Miller FD, Barker PA: Transgenic mice expressing the intracellular domain of the p75 neurotrophin receptor undergo neuronal apoptosis. J Neurosci 1997, 17(18):6988-6998

31. Domeniconi M, Zampieri N, Spencer T, Hilaire M, Mellado W, Chao MV Filbin MT: MAG induces regulated intramembrane proteolysis of the p75 neurotrophin receptor to inhibit neurite outgrowth. Neuron 2005 , 46(6):849-855

32. Kenchappa RS, Zampieri N, Chao MV, Barker PA, Teng HK, Hempstead BL, Carter BD: Ligand-dependent cleavage of the P75 neurotrophin receptor is necessary for NRIF nuclear translocation and apoptosis in sympathetic neurons. Neuron 2006, 50(2):219-232.

33. Srinivasan B, Wang Z, Brun-Zinkernagel AM, Collier RJ, Black RA, Frank SJ, Barker PA, Roque RS: Photic injury promotes cleavage of p75NTR by TACE and nuclear trafficking of the p75 intracellular domain. Mol Cell Neurosci 2007, 36(4):449-461.

34. Coulson EJ, May LM, Osborne SL, Reid K, Underwood CK, Meunier FA, Bartlett PF, Sah P: p75 neurotrophin receptor mediates neuronal cell death by activating GIRK channels through phosphatidylinositol 4, 5-bisphosphate. J Neurosci 2008, 28(1):315-324.

35. Underwood CK, Reid K, May LM, Bartlett PF, Coulson EJ: Palmitoylation of the C-terminal fragment of $\mathrm{p75}(\mathrm{NTR})$ regulates death signaling and is required for subsequent cleavage by gamma-secretase. Mol Cell Neurosci 2008, 37(2):346-358.

36. Wang L, Rahn JJ, Lun X, Sun B, Kelly JJ, Weiss S, Robbins SM, Forsyth PA, Senger DL: Gamma-secretase represents a therapeutic target for the treatment of invasive glioma mediated by the $\mathrm{p} 75$ neurotrophin receptor. PLOS Biol 2008, 6(11):e289.

37. Ceni C, Kommaddi RP, Thomas R, Vereker E, Liu X, McPherson PS, Ritter B, Barker PA: The p75NTR intracellular domain generated by neurotrophin-induced receptor cleavage potentiates Trk signaling. J Cell Sci 2010, 123(Pt 13):2299-2307

38. Kenchappa RS, Tep C, Korade Z, Urra S, Bronfman FC, Yoon SO, Carter BD: p75 neurotrophin receptor-mediated apoptosis in sympathetic neurons involves a biphasic activation of JNK and up-regulation of tumor necrosis factor-alphaconverting enzyme/ADAM17. J Biol Chem 2010, 285(26):20358-20368.

39. Kommaddi RP, Thomas R, Ceni C, Daigneault K, Barker PA: Trk-dependent ADAM17 activation facilitates neurotrophin survival signaling. FASEB J 2011, 25(6):2061-2070.

40. Urra S, Escudero CA, Ramos P, Lisbona F, Allende E, Covarrubias P, Parraguez Jl, Zampieri N, Chao MV, Annaert W, Bronfman FC: TrkA receptor activation by nerve growth factor induces shedding of the p75 neurotrophin receptor followed by endosomal gamma-secretasemediated release of the p75 intracellular domain. J Biol Chem 2007, 282(10):7606-7615.

41. Forster E, Bock HH, Herz J, Chai XJ, Frotscher M, Zhao ST: Emerging topics in Reelin function. Eur J Neurosci 2010, 31(9):1511-1518.

42. Ogawa M, Miyata T, Nakajima K, Yagyu K, Seike M, Ikenaka K, Yamamoto H, Mikoshiba K: The Reeler gene-associated antigen on Cajal-Retzius neurons is a crucial molecule for laminar organization of cortical-neurons. Neuron 1995, 14(5):899-912.

43. DelRio JA, Heimrich B, Borrell V, Forster E, Drakew A, Alcantara S, Nakajima K, Miyata T, Ogawa M, Mikoshiba K, Derer P, Frotscher M, Soriano E: A role for Cajal-Retzius cells and reelin in the development of hippocampal connections. Nature 1997, 385(6611):70-74.

44. Trommsdorff M, Gotthardt M, Hiesberger T, Shelton J, Stockinger W, Nimpf J, Hammer RE, Richardson JA, Herz J: Reeler/Disabled-like disruption of neuronal migration in knockout mice lacking the VLDL receptor and ApoE receptor 2. Cell 1999, 97(6):689-701.

45. Drakew A, Deller T, Heimrich B, Gebhardt C, Del Turco D, Tielsch A, Forster E, Herz J, Frotscher M: Dentate granule cells in reeler mutants and VLDLR and ApoER2 knockout mice. Exp Neurol 2002, 176(1):12-24.

46. Gebhardt C, Del Turco D, Drakew A, Tielsch A, Herz J, Frotscher M, Deller T: Abnormal positioning of granule cells alters afferent fiber distribution in the mouse fascia dentata: morphologic evidence from reeler apolipoprotein E receptor 2-, and very low density lipoprotein receptor knockout mice. J Comp Neurol 2002, 445(3):278-292.

47. Beffert U, Durudas A, Weeber EJ, Stolt PC, Giehl KM, Sweatt JD, Hammer RE, Herz J: Functional dissection of Reelin signaling by site-directed disruption of Disabled-1 adaptor binding to apolipoprotein $\mathrm{E}$ receptor 2: distinct roles in development and synaptic plasticity. J Neurosci 2006, 26(7):2041-2052.

48. Beffert U, Weeber EJ, Durudas A, Qiu S, Masiulis I, Sweatt JD, Li WP, Adelmann G, Frotscher M, Hammer RE, Herz J: Modulation of synaptic plasticity and memory by Reelin involves differential splicing of the lipoprotein receptor Apoer2. Neuron 2005, 47(4):567-579.

49. Dumanis SB, Cha HJ Song JM, Trotter JH, Spitzer M, Lee JY, Weeber EJ Turner RS, Pak DT, Rebeck GW, Hoe HS: ApoE receptor 2 regulates synapse and dendritic spine formation. PLOS One 2011, 6(2):e17203.

50. Chai X, Forster E, Zhao S, Bock HH, Frotscher M: Reelin stabilizes the actin cytoskeleton of neuronal processes by inducing $n$-cofilin phosphorylation at serine3. J Neurosci 2009, 29(1):288-299.

51. Leemhuis J, Bouche E, Frotscher M, Henle F, Hein L, Herz J, Meyer DK, Pichler M, Roth G, Schwan C, Bock HH: Reelin signals through apolipoprotein E receptor 2 and Cdc42 to increase growth cone motility and filopodia formation. J Neurosci 2010, 30(44):14759-14772. 
52. Beffert U, Nematollah Farsian F, Masiulis I, Hammer RE, Yoon SO, Giehl KM, Herz J: ApoE receptor 2 controls neuronal survival in the adult brain. Curr Biol 2006, 16(24):2446-2452.

53. Kysenius K, Muggalla P, Matlik K, Arumae U, Huttunen HJ: PCSK9 regulates neuronal apoptosis by adjusting ApoER2 levels and signaling. Cell Mol Life Sci 2012, 69(11):1903-1916.

54. D'Arcangelo G, Homayouni R, Keshvara L, Rice DS, Sheldon M, Curran T: Reelin is a ligand for lipoprotein receptors. Neuron 1999, 24(2):471-479.

55. Strasser V, Fasching D, Hauser C, Mayer H, Bock HH, Hiesberger T, Herz J, Weeber EJ, Sweatt JD, Pramatarova A, Howell B, Schneider WJ, Nimpf J: Receptor clustering is involved in Reelin signaling. Mol Cell Biol 2004, 24(3):1378-1386.

56. Morimura T, Hattori M, Ogawa M, Mikoshiba K: Disabled1 regulates the intracellular trafficking of reelin receptors. J Biol Chem 2005, 280(17):16901-16908.

57. Hiesberger T, Trommsdorff M, Howell BW, Goffinet A, Mumby MC, Cooper JA, Herz J: Direct binding of Reelin to VLDL receptor and ApoE receptor 2 induces tyrosine phosphorylation of disabled-1 and modulates tau phosphorylation. Neuron 1999, 24(2):481-489.

58. Howell BW, Herrick TM, Cooper JA: Reelin-induced tyrosine [corrected] phosphorylation of disabled 1 during neuronal positioning. Genes Dev 1999, 13(6):643-648.

59. Bock HH, Herz J: Reelin activates SRC family tyrosine kinases in neurons. Curr Biol 2003, 13(1):18-26.

60. Bock HH, Jossin Y, Liu P, Forster E, May P, Goffinet AM, Herz J: Phosphatidylinositol 3-kinase interacts with the adaptor protein Dab1 in response to Reelin signaling and is required for normal cortical lamination. J Biol Chem 2003, 278(40):38772-38779.

61. Chai $X$, Forster E, Zhao S, Bock HH, Frotscher M: Reelin acts as a stop signal for radially migrating neurons by inducing phosphorylation of $n$-cofilin at the leading edge. Commun Integr Biol 2009, 2(4):375-377.

62. Beffert U, Morfini G, Bock HH, Reyna H, Brady ST, Herz J: Reelin-mediated signaling locally regulates protein kinase B/Akt and glycogen synthase kinase 3beta. J Biol Chem 2002, 277(51):49958-49964.

63. Duit S, Mayer H, Blake SM, Schneider WJ, Nimpf J: Differential functions of ApoER2 and very low density lipoprotein receptor in Reelin signaling depend on differential sorting of the receptors. J Biol Chem 2010, 285(7):4896-4908

64. Hoe HS, Rebeck GW: Regulation of ApoE receptor proteolysis by ligand binding. Brain Res Mol Brain Res 2005, 137(1-2):31-39.

65. Hoe HS, Wessner D, Beffert U, Becker AG, Matsuoka Y, Rebeck GW: F-spondin interaction with the apolipoprotein E receptor ApoEr2 affects processing of amyloid precursor protein. Mol Cell Biol 2005, 25(21):9259-9268

66. Lang UE, Puls I, Muller DJ, Strutz-Seebohm N, Gallinat J: Molecular mechanisms of schizophrenia. Cell Physiol Biochem 2007, 20(6):687-702

67. Shi Y, Mantuano E, Inoue G, Campana WM, Gonias SL: Ligand binding to LRP1 transactivates Trk receptors by a Src family kinase-dependent pathway. Sci Signal 2009, 2(68):ra18.

68. Greene LA, Tischler AS: Establishment of a noradrenergic clonal line of rat adrenal pheochromocytoma cells which respond to nerve growth factor. Proc Natl Acad Sci U S A 1976, 73(7):2424-2428.

69. Greene LA: Nerve growth factor prevents the death and stimulates the neuronal differentiation of clonal PC12 pheochromocytoma cells in serum-free medium. J Cell Biol 1978, 78(3):747-755.

70. Niu S, Renfro A, Quattrocchi CC, Sheldon M, D'Arcangelo G: Reelin promotes hippocampal dendrite development through the VLDLR/ApoER2-Dab1 pathway. Neuron 2004, 41(1):71-84.

71. Sotelo P, Farfan P, Benitez ML, Bu G, Marzolo MP: Sorting Nexin 17 Regulates ApoER2 Recycling and Reelin Signaling. PLoS One 2014, 9(4):e93672.

72. Weskamp G, Schlondorff J, Lum L, Becherer JD, Kim TW, Saftig P, Hartmann D, Murphy G, Blobel CP: Evidence for a critical role of the tumor necrosis factor alpha convertase (TACE) in ectodomain shedding of the p75 neurotrophin receptor (p75NTR). J Biol Chem 2004, 279(6):4241-4249.

73. Hoe HS, Cooper MJ, Burns MP, Lewis PA, van der Brug M, Chakraborty G, Cartagena CM, Pak DT, Cookson MR, Rebeck GW: The metalloprotease inhibitor TIMP-3 regulates amyloid precursor protein and apolipoprotein E receptor proteolysis. J Neurosci 2007, 27(40):10895-10905.

74. Ohkubo N, Vitek MP, Morishima A, Suzuki Y, Miki T, Maeda N, Mitsuda N: Reelin signals survival through Src-family kinases that inactivate BAD activity. J Neurochem 2007, 103(2):820-830.
75. Kong DX, Yamori T: ZSTK474, a novel phosphatidylinositol 3-kinase inhibitor identified using the JFCR39 drug discovery system. Acta Pharmaco/ Sin 2010, 31(9):1189-1197.

76. Carpentier S, N'Kuli F, Grieco G, Van Der Smissen P, Janssens V, Emonard H, Bilanges B, Vanhaesebroeck B, Gaide Chevronnay HP, Pierreux CE, Tyteca D, Courtoy PJ: Class III phosphoinositide 3-kinase/VPS34 and dynamin are critical for apical endocytic recycling. Traffic 2013, 14(8):933-948.

77. Barr AM, Fish KN, Markou A: The reelin receptors VLDLR and ApoER2 regulate sensorimotor gating in mice. Neuropharmacology 2007, 52(4):1114-1123.

78. D'Arcangelo G: Apoer2: a reelin receptor to remember. Neuron 2005, 47(4):471-473

79. Soond SM, Everson B, Riches DW, Murphy G: ERK-mediated phosphorylation of Thr735 in TNFalpha-converting enzyme and its potential role in TACE protein trafficking. J Cell Sci 2005, 118(Pt 11):2371-2380.

80. Xu P, Liu J, Sakaki-Yumoto M, Derynck R: TACE activation by MAPKmediated regulation of cell surface dimerization and TIMP3 association. Sci Signal 2012, 5(222):ra34

81. Van Schaeybroeck S, Kyula JN, Fenton A, Fenning CS, Sasazuki T, Shirasawa S, Longley DB, Johnston PG: Oncogenic Kras promotes chemotherapyinduced growth factor shedding via ADAM17. Cancer Res 2011, 71(3):1071-1080

82. Gruenberg J: Lipids in endocytic membrane transport and sorting Curr Opin Cell Biol 2003, 15(4):382-388

83. Di Paolo G, De Camilli P: Phosphoinositides in cell regulation and membrane dynamics. Nature 2006, 443(7112):651-657.

84. Spiro DJ, Boll W, Kirchhausen T, Wessling-Resnick M: Wortmannin alters the transferrin receptor endocytic pathway in vivo and in vitro. Mol Biol Cell 1996, 7(3):355-367.

85. Brabec M, Blaas D, Fuchs R: Wortmannin delays transfer of human rhinovirus serotype 2 to late endocytic compartments. Biochem Biophys Res Commun 2006, 348(2):741-749.

86. Hill RA, Wu YW, Gogos A, van den Buuse M: Sex-dependent alterations in BDNF-TrkB signaling in the hippocampus of reelin heterozygous mice: role for sex steroid hormones. J Neurochem 2013, 126(3):389-399.

87. Ringstedt T, Linnarsson S, Wagner J, Lendahl U, Kokaia Z, Arenas E, Ernfors P, Ibanez CF: BDNF regulates reelin expression and Cajal-Retzius cell development in the cerebral cortex. Neuron 1998, 21(2):305-315.

88. Do HT, Bruelle C, Tselykh T, Jalonen P, Korhonen L, Lindholm D: Reciprocal regulation of very low density lipoprotein receptors (VLDLRs) in neurons by brain-derived neurotrophic factor (BDNF) and Reelin: involvement of the E3 ligase Mylip/Idol. J Bio/ Chem 2013, 288(41):29613-29620.

89. Pillai A, Mahadik SP: Increased truncated TrkB receptor expression and decreased BDNF/TrkB signaling in the frontal cortex of reeler mouse model of schizophrenia. Schizophr Res 2008, 100(1-3):325-333.

90. Balmaceda V, Cuchillo-Ibanez I, Pujadas L, Garcia-Ayllon MS, Saura CA, Nimpf J, Soriano E, Saez-Valero J: ApoER2 processing by presenilin-1 modulates reelin expression. FASEB J 2014, 28(4):1543-1554

91. Nieto R, Kukuljan M, Silva H: BDNF and schizophrenia: from neurodevelopment to neuronal plasticity, learning, and memory. Front Psychiatr 2013, 4:45.

92. Eisenberg DP, lanni AM, Wei SM, Kohn PD, Kolachana B, Apud J, Weinberger DR, Berman KF: Hippocampal dysfunction in schizophrenia: association with brain-derived neurotrophic factor genotype. Mol Psychiatry 2013, 18(6):631.

93. Fatemi SH: Reelin mutations in mouse and man: from reeler mouse to schizophrenia, mood disorders, autism and lissencephaly. Mol Psychiatry 2001, 6(2):129-133.

94. Fatemi SH: Reelin glycoprotein in autism and schizophrenia. Int Rev Neurobio/ 2005, 71:179-187.

95. lafrati J, Orejarena MJ, Lassalle O, Bouamrane L, Chavis P: Reelin, an extracellular matrix protein linked to early onset psychiatric diseases, drives postnatal development of the prefrontal cortex via GluN2B-NMDARs and the mTOR pathway. Mol Psychiatry 2014, 19(4):417-426.

96. Das UN: Autism as a disorder of deficiency of brain-derived neurotrophic factor and altered metabolism of polyunsaturated fatty acids. Nutrition 2013, 29(10):1175-1185.

97. Abdallah MW, Mortensen EL, Greaves-Lord K, Larsen N, Bonefeld-Jorgensen EC, Norgaard-Pedersen B, Hougaard DM, Grove J: Neonatal levels of neurotrophic factors and risk of autism spectrum disorders. Acta Psychiatr Scand 2013, 128(1):61-69. 
98. Sheikh AM, Malik M, Wen G, Chauhan A, Chauhan V, Gong CX, Liu F, Brown WT, Li X: BDNF-Akt-BCl2 antiapoptotic signaling pathway is compromised in the brain of autistic subjects. J Neurosci Res 2010, 88(12):2641-2647.

99. Koch S, Strasser V, Hauser C, Fasching D, Brandes C, Bajari TM, Schneider WJ, Nimpf $\mathrm{J}$ : A secreted soluble form of ApoE receptor 2 acts as a dominant-negative receptor and inhibits Reelin signaling. EMBO J 2002, 21(22):5996-6004.

100. May P, Bock HH, Nimpf J, Herz J: Differential glycosylation regulates processing of lipoprotein receptors by gamma-secretase. J Biol Chem 2003, 278(39):37386-37392.

101. Fuentealba RA, Barria MI, Lee J, Cam J, Araya C, Escudero CA, Inestrosa NC, Bronfman FC, Bu G, Marzolo MP: ApoER2 expression increases Abeta production while decreasing Amyloid Precursor Protein (APP) endocytosis: possible role in the partitioning of APP into lipid rafts and in the regulation of gamma-secretase activity. Mol Neurodegener 2007, 2:14.

102. Cuitino L, Matute R, Retamal C, Bu G, Inestrosa NC, Marzolo MP: ApoER2 is endocytosed by a clathrin-mediated process involving the adaptor protein Dab2 independent of its Rafts' association. Traffic 2005, 6(9):820-838.

doi:10.1186/1471-2202-15-108

Cite this article as: Larios et al:: Neurotrophins regulate ApoER2 proteolysis through activation of the Trk signaling pathway. BMC Neuroscience 2014 15:108.

\section{Submit your next manuscript to BioMed Central and take full advantage of:}

- Convenient online submission

- Thorough peer review

- No space constraints or color figure charges

- Immediate publication on acceptance

- Inclusion in PubMed, CAS, Scopus and Google Scholar

- Research which is freely available for redistribution 